OPEN ACCESS

Edited by:

Rajni Singh

Amity University, India

Reviewed by:

Divjot Kour,

Southern Federal University, Russia

Sanjeev Kumar,

National Dairy Research Institute

(ICAR), India

Abhijeet Shankar Kashyap,

National Bureau of Agriculturally

Important Microorganisms

(ICAR), India

*Correspondence:

Padmanabh Dwivedi

pdwivedi25@rediffmail.com

†These authors have contributed equally to this work

Specialty section: This article was submitted to

Plant-Soil Interactions,

a section of the journal

Frontiers in Agronomy

Received: 15 June 2021 Accepted: 23 December 2021

Published: 28 January 2022

Citation:

Sharma B, Singh BN, Dwivedi $P$ and Rajawat MVS (2022) Interference of

Climate Change on Plant-Microbe Interaction: Present and Future

Prospects. Front. Agron. 3:725804.

doi: 10.3389/fagro.2021.725804

\section{Interference of Climate Change on Plant-Microbe Interaction: Present and Future Prospects}

\author{
Binny Sharma ${ }^{1}$, Bansh Narayan Singh ${ }^{1,2 \dagger}$, Padmanabh Dwivedi ${ }^{1 * t}$ and \\ Mahendra Vikram Singh Rajawat ${ }^{3}$ \\ ${ }^{1}$ Department of Plant Physiology, Institute of Agricultural Sciences, Banaras Hindu University, Varanasi, India, ${ }^{2}$ Institute of \\ Environment \& Sustainable Development, Banaras Hindu University, Varanasi, India, ${ }^{3}$ National Bureau of Agriculturally \\ Important Microorganisms, Kushmaur, India
}

Plant mutualistic association with various beneficial microbes is referred to as the plant enhancer microbiome. These microbes are found either in episphere or endosphere of the plant tissues. Several pieces of evidence have highlighted that plant microbiomes and soil play a pivotal role in making soil nutrient balance which is readily available to plants and provide strength under various stresses. Recently different technologies relevant to plant microbiome and diversity such as sequencing technologies, metagenomics, and bioinformatics have been utilized. Knowledge about factors that shape the composition of plant microbes is still less explored. Here, current insights into the issues driving the above/below plant microbial diversities are explored. Primarily, we address the distribution of microbial communities above and below ground across plant habitats that has benefitted plants. Microbial communities are efficient regulators of biogeochemical cycle which is a better approach to mitigate changing climatic patterns aids in proper utilization of greenhouse gases for their metabolic mechanisms. The present review is thereby significant for assessing microbiome mitigation toward climate change and multiple avenues of plant- microbe interaction under commuting climatic scenario. Finally, we summarize factors that promote the structure and composition of the plant microbiome.

Keywords: climate resilience, environmental factors, niche communities, plant-microbe, interactions, microbiome, sustainable

\section{INTRODUCTION}

Over the past few decades, several anthropogenic and natural activities stimulated the rise in average temperature and carbon dioxide levels which cause changes in climatic conditions globally. These changing climatic conditions involve erratic events like increase in rainfall and snowfall worldwide, excessive release of greenhouse gases, increase in air temperature which renders soil dry and decrease its moisture content forming drought lie conditions. Some other consequences consist of increase in pollution due to increased $\mathrm{CO}_{2}$ emissions, air pollutants, ground- level ozone, aerosols, methane, and others. It induces seasonal variations by altering wind patterns. In other terms, climate change involves the transposing of climatic or weather patterns that occur by emission of greenhouse gases which are likely to be more erratic and extreme in the forthcoming years. Statistical evidence presented by International Panel of Climate Change 2019 states that within food systems, during 2007-2016, the agricultural design (including crop production 
and livestock management) generated $142 \pm 42 \mathrm{Tg} \mathrm{CH} 4 \mathrm{yr}^{-1}$,

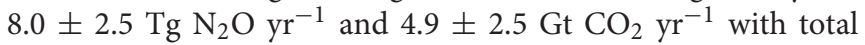
greenhouse gas emission $6.2 \pm 1.44 \mathrm{t} \mathrm{CO}_{2}-\mathrm{eq} \mathrm{yr}^{-1}$ to $11.1 \pm 2.9$ $\mathrm{Gt} \mathrm{CO}_{2}$-eq $\mathrm{yr}^{-1}$ (Jia et al., 2019). It is likely to increase about $30-$ $40 \%$ by 2050 . These climatic conditions may affect food security through an elevation in temperature, changing rainfall patterns, extreme events, and many more. Studies conducted revealed that the climatic variations affect the crop yields in lower- and higher-latitude regions differently. For instance, the changing climatic trends impart significant drought across Ethiopia, which causes widespread crop failure and food aid to the majority of people in that region (USDA., 2016; Huntington et al., 2017). Climate alterations influence the growth behavior of different crop species. Like, it has huge impact on nutrient acquisition and mineral accumulation in the plants.

Direct effects on the plants includes morphological changes, physiological and phenotypic changes, and changes in plant productivity. Due to stress conditions, the organs ad membranes of plants are impaired. The increased oxidative stress adversely influences the production of carbohydrates, proteins, secondary metabolite in the plants. It also affects soil fertility, irrigation measures, pests and diseases occurrence, and stress incidence like heat, drought. The other ill effects of climate change on production strategies includes effect on food demand, trade opportunities and unequal distribution of products (Raza et al., 2019). These alterations thus cause a negative impact on plant growth and developmental patterns and microbiomes present in the soil.

Like plants, the soil is also a home for many microorganisms like bacteria, fungi, protist, viruse and many others, which may be beneficial, neutral or pathogenic. It is a well-recognized fact that these microbiomes are key indicators of plant health and play an important role in productivity and growth (Berg et al., 2016). Microbiome is a contributor of multiple aspects of plant system. They regulate plant health through their antagonist and synergistic behavior in association with the plants. They influence plant system through metabolic cooperation, inducing signaling responses and microbial dysbiosis. Studies made regarding the phenomenon by which plants acquire defense mechanism against pathogenic microorganisms and get benefitted from beneficial ones have gained much attention in recent few years. Many researchers explored basic principles of interaction with plant and microbiota, signaling process of plant defense and symbiotic responses toward microbes (Jones et al., 2016), a genetic system of microbes that transport signaling molecule to modulate host cell functions (Hwang et al., 2017) and specific binary and community level conflict in plant and microbial interactions (Hacquard et al., 2017). The study of environmental impact on plant and microbiome interaction is seldom at mechanistic and molecular levels, thus, unravels the new avenues in exploring the plant and microbial association in nature mediating ecological resilience. The present review describes large microbial population that exists in the environment, their growth patterns, along with ecological functions. Secondly, it describes the effect of changing climatic conditions on microbial diversity present in nature by a designed framework to develop a better understanding of the influence of climate on plant-microbe interaction as well.

\section{Microbial Diversity}

The interaction of plants with microbiota is unavoidable and inseparable. Plants and soil harbor a wide range of microbiome which may be present inside (endosphere) and outside (episphere) the plant tissues (Khondoker et al., 2020). Soil can be considered a repository of microbial populations, whereas plants interact with surplus microbes and other entities present in nature. The microbial communities differ significantly in rhizosphere, endosphere, and phyllosphere in the environment (Trivedi et al., 2020). Plants and microbial population encompasses to form a "holobiont." In general terms, holobiont can be defined as the assemblage or association of a host with various species surrounding it, together forming an ecological unit. Microbiota which interacts with plants have a diverse location, ecological function in both aboveground and below-ground environment and poses a potential role in regulating resistance to climatic alterations and other stress responses.

\section{Above-Ground Plant-Microbiome Interaction}

Plants including stems, leaves and their other parts contain abundant microscopic organisms like bacteria (Proteobacteria, Bacteriodetes), actinomycetes, fungi (Ascomycota and Basidiomycota), viruses, and others (Figure 1). The region surrounding the aerial portion of the plant is termed the phyllosphere. Different plant species possess a diverse range of microbiota in their phyllosphere region (Table 1). The phyllosphere region is very dynamic and greatly influenced by several factors like temperature, precipitation, light, etc. The bacterial population present in the phyllosphere $\alpha$ and $\gamma$ proteobacteria belong to proteobacterial (phyla- Bacteriodetes \& Actinobacteria) that are mostly non-pathogenic and hyperdiverse in nature. The phyllosphere fungi associated with forest trees are saprobic and key decomposers of leaf litter along with another group which are latent pathogens (Osono, 2006). Similarly, numerous studies on several crops like apple, almond, tobacco, pumpkin and many others concluded that Pseudomonas are the most abundant in these crops (Aleklett et al., 2014). Phyllosphere also consists of diverse group of algal microbiome, although the study of phyllospheric microbiome is seldom. Algae are aquatic organisms having diverse groups including green microalgae, cyanobacteria along with different classes namely chlorophyceae, Dinophyceae, Eustigamatophyceae, Trebouxiophyceae, and Ulvophyceae. These species are abundant in tropical trees, mangrove forests, Taiwan rain forests, and rice crop (Lin et al., 2012; Venkatachalam et al., 2016; Zhu et al., 2018). The Atlantic forest phyllosphere has diverse and rich communities of cyanobacteria (Rigonato et al., 2016). The algal groups like Nostocales and Oscillatoriales occurs predominantly in the phyllospheric region. Thus, the above evidence is enough to conclude the fact that microbiota is not only abundant but diverse in the phyllosphere in the plants. However, the core phyllospheric regions also contain pathogenic microbiota, which is often dramatic systemic and spreads vigorously to 


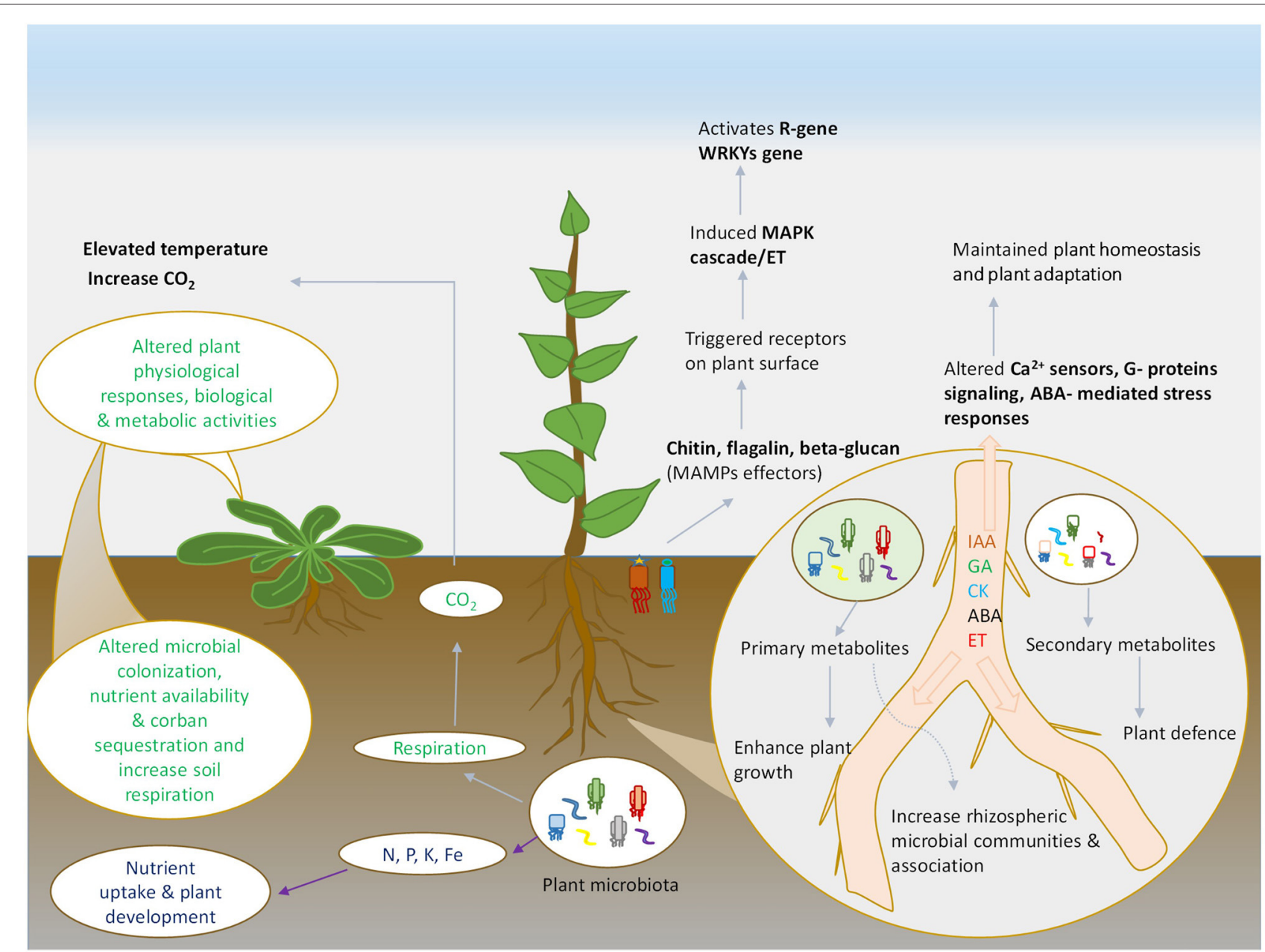

FIGURE 1 | Schematic representation of plant and microbes interaction. Various plant and microbes derived compounds that shape the microbial community and altered the plant immunity under environmental stresses.

cause diseases in plants (Stone et al., 2018). The increased interest in phyllosphere research has disclosed the new aspects in understanding plant health, ecological principles, and atmospheric chemistry, but there are still many aspects that needed to be explored. The use of modern approaches like proteogenomics, community-based next-generation sequencing, metaproteomics, offers a great aid in understanding the role of novel proteins that stimulate phyllospheric growth. Although in situ interaction of microorganisms with phyllosphere using complementary approaches at microscale is needed to be attended thoroughly (Figure 1).

In contrast, fungal diversity is expected to remain lower. The endophytic fungi form a mutualistic symbiotic association with some plants, grasses, legumes, morning glory, thus producing bioactive metabolites, and perform defense mechanisms (Panaccione et al., 2014) and obligatory plant-associated. Fungal and bacterial endophytes present in plant ecosystems have a diverse role which includes stress resistance, increase biomass and decreased water consumption, altered resource allocation. They can be non-pathogenic for at least part of their life cycle (Rodriguez et al., 2009). The transmission of bacterial endophytes can commence either by seed, pollen, soil, atmosphere, insects, wind, or water (Frank et al., 2017). The study of endospheric and phyllospheric variability of grapevine revealed the presence of diverse genera, which included Pseudomonas, Sphingomonas, Enterobacteria, Bacillus, Erwinia, Methylobacteria like organisms (Compant et al., 2019), while maize leaves predominantly contained Sphingomonads and Methylobacteria in diverse maize lines (Wallace et al., 2018). Thompson et al. (1993) studied the presence of 1,236 bacterial strains on immature, mature and senescent leaves of sugarbeet over a complete growing life cycle of a plant.

\section{Below-Ground Plant-Microbe Interaction}

Soil is a habitat of plenty of microorganisms that supports life forms and anchors the root system of the plants. Plant roots contain a diverse form of microfauna, either endophytic or rhizospheric (Table 1). The rhizosphere is the region of soil adjacent to plant roots that harbors an environment for plant roots with microorganisms. Similar to phyllospheric region, the diverse microbiota in the rhizosphere can also be dispersed through air, soil, water, insects, animals, etc. Soil 
TABLE 1 | Microbial communities present in phyllospheric and rhizospheric regions of different plant species.

\begin{tabular}{|c|c|c|}
\hline Microbial species & Plant species & References \\
\hline $\begin{array}{l}\text { Sphingomonads and } \\
\text { Methylobacteria }\end{array}$ & Maize & Wallace et al., 2018 \\
\hline Pseudomonas & $\begin{array}{l}\text { Apple, almond, } \\
\text { tobacco }\end{array}$ & Aleklett et al., 2014 \\
\hline $\begin{array}{l}\text { Pseudomonas, Erwinia } \\
\text { herbicola }\end{array}$ & Sugarbeet & Thompson et al., 1993 \\
\hline Proteobacteria & $\begin{array}{l}\text { Soybean, clover, rice, } \\
\text { Arabidopsis }\end{array}$ & Vorholt, 2012 \\
\hline $\begin{array}{l}\text { Undifilum spp., } \\
\text { Clavicipitaceous fungi }\end{array}$ & $\begin{array}{l}\text { Legumes, Morning } \\
\text { glory }\end{array}$ & Panaccione et al., 2014 \\
\hline $\begin{array}{l}\text { Ascochyta species, } \\
\text { Colletotrichum } \\
\text { gloeosporioides, Phomopsis } \\
\text { species }\end{array}$ & $\begin{array}{l}\text { Fagus species, Swida } \\
\text { species }\end{array}$ & Osono, 2006 \\
\hline $\begin{array}{l}\text { Pseudomonas, } \\
\text { Sphingomonas, } \\
\text { Frigoribacterium }\end{array}$ & $\begin{array}{l}\text { Grapevine, grape } \\
\text { clusters }\end{array}$ & Compant et al., 2019 \\
\hline $\begin{array}{l}\text { Green microalgae, } \\
\text { cyanobacteria }\end{array}$ & $\begin{array}{l}\text { Mangrove forests, } \\
\text { Taiwan rain forests, } \\
\text { rice, tropical trees }\end{array}$ & $\begin{array}{l}\text { Lin et al., 2012; } \\
\text { Venkatachalam et al., } \\
\text { 2016; Zhu et al., } 2018\end{array}$ \\
\hline $\begin{array}{l}\text { Pseudomonas, } \\
\text { Agrobacterium, } \\
\text { Cupriavidus, Rhizobium }\end{array}$ & Citrus species & Xu et al., 2018 \\
\hline $\begin{array}{l}\text { Proteobacteria, } \\
\text { Acidobacteria, } \\
\text { Actinobacteria, } \\
\text { Bacteriodetes, } \\
\text { Plantomycetes, Choloroflexi, } \\
\text { Gemmatimonatedes }\end{array}$ & Grapevine & $\begin{array}{l}\text { Faist et al., 2016; Samad } \\
\text { et al., } 2017\end{array}$ \\
\hline $\begin{array}{l}\text { Proteobacteria, } \\
\text { Actinobacteria }\end{array}$ & $\begin{array}{l}\text { Cucumber, tomato, } \\
\text { wheat maize }\end{array}$ & $\begin{array}{l}\text { Reinhold-Hurek et al., } \\
2015\end{array}$ \\
\hline $\begin{array}{l}\text { Bacteroidetes, } \\
\text { Actinobacteria, } \\
\text { Ascomycota, } \\
\text { Basidiomycota, } \\
\text { Olpidiomycota }\end{array}$ & Arabidopsis & Bergelson et al., 2019 \\
\hline PGPR & Jerusalem artichoke & Montalbán et al., 2017 \\
\hline $\begin{array}{l}\text { Acidobacteria, } \\
\text { Alphaproteobacteria, and } \\
\text { Gammaproteobacteria }\end{array}$ & Cottonwood & Timm et al., 2018 \\
\hline $\begin{array}{l}\text { Orchidaceous mycorrhizal } \\
\text { fungi }\end{array}$ & Orchids & Rudgers et al., 2020 \\
\hline Nostoc, Anabaena & Rice & Prasanna et al., 2009 \\
\hline Calothrix, Scytonema & Paddy & Roger et al., 1993 \\
\hline
\end{tabular}

harbor's a wide range of bacteria, actinomycetes, fungi, and other microorganisms which interact with plant parts; some are mutualistically associated (PGPR, Rhizobia) while others perform vital ecological functions. e.g., the citrus rhizospheric microbiome contains diverse groups of microbiota that mainly includes Pseudomonas, Agrobacterium, Cupriavidus, Rhizobium, Sphingomonas, and many others as potential beneficial microbes (Jin et al., 2018; Xu et al., 2018). Root exudates like organic acids, amino acids, fatty acids, plant growth regulators, sugars, vitamins, and other metabolites have a pronounced effect on the availability and composition of microorganisms around roots (Compant et al., 2019). However, the plant roots are colonized by a diverse group of bacterial and fungal endophytes that are present internally. The endophytes enter plant roots passively by penetrating the sites of cracks at root emergence region, root tips, through lateral roots and also through an active process.

Seeds, on the other hand, are important sources for microbial proliferation in the roots. In grapevine roots, the bacterial phyla that are abundant include Proteobacteria, Acidobacteria, Actinobacteria, Bacteriodetes, Plantomycetes, Choloroflexi, Gemmatimonatedes (Faist et al., 2016; Samad et al., 2017). The symbiotic association of fungi with roots in the form of endophytes and mycorrhiza are key factors in nutrient acquisition and root colonization (Kariman et al., 2018; Li et al., 2018). The roots of cucumber, tomato, wheat and maize were dominated by Proteobacteria, Actinobacteria with relative abundance in the $\gamma$-proteobacteria and $\alpha$-proteobacteria (Reinhold-Hurek et al., 2015). In a similar manner, the root endosphere and rhizosphere in $A$. thaliana were colonized by abundant bacterial species that included Bacteroidetes, Actinobacteria, Proteobacteria, Chloroflexi, Firmicutes, Acidobacteria, Saccharibacteria along with fungal phylum viz., namely Ascomycota, Basidiomycota, Olpidiomycota, Chytridiomycota and many more species (Bergelson et al., 2019).

The nitrogen-fixing bacteria (Rhizobium, Frankia) form a symbiotic association with Fabaceae in specialized nodules to fix atmospheric nitrogen into nitrate, which can be utilized by plants (Menge et al., 2019). Studies conducted on PGPR revealed that they had a pronounced effect on phytoremediation strategies. In Helianthus tuberosis, PGPR growing endophytically in roots showed considerable resistance to elevated concentration of cadmium and zinc (Montalbán et al., 2017). The rhizosphere and endosphere of the Populus genus contain an abundance of Acidobacteria, Alphaproteobacteria, and Gammaproteobacteria (Actinobacteria) that play a major part in stress-specific and core stress responses (Timm et al., 2018). Plant species contains diverse range of arbuscular mycorrhizal fungi in Glomeromycotina along with a smaller part of ectomycorrhizal fungi (Ascomycota and Basidiomycota) distributed geographically (Rudgers et al., 2020). Different plant species harbor different fungal groups e.g., Ercoid fungi in Ascomycota are commonly associated with the ericaceous plant, while Basidiomycota (Orchidaceous mycorrhizal fungi) are found in orchids. Prasanna et al. (2009) identified cyanobacterial species Nostoc and Anabaena in the rhizospheric region of rice crop. Cyanobacterial species like Calothrix, Scytonema are dominant in paddy fields (Roger et al., 1993). Another algal species abundant in rhizosphere also include Oscillatoria and Phormidium. Plant roots contain pathogenic and non-pathogenic fungi. The hyaline and melanized ascomycetes fungal group are dominant in the roots of prariers (Jumpponen et al., 2017). Thus, the rhizospheric microorganisms have vast diversity among different plant species. They play a pivotal role in the physiology and development of plants. The approaches of nextgeneration sequencing, 16sRNA gene sequencing, ITS, CRISPR, and genome editing molecular tools have provided a better understanding of the interaction of microbiota with roots and 
below-ground level. Also, incorporating traditional approaches with modern gene sequencing technique will bring new insights to explore the microbial life in the rhizosphere. Knowledge of microbial population, its functioning and activities aid in the identification of suitable microbial candidate to support plant growth and health in various environmental conditions and disease suppression (Mendes et al., 2013).

\section{Plant-Beneficial Microbes}

The role of microorganisms in understanding plant production and ecological sustainability has been deciphered since ancient times. Plants possess a huge variety of microbiomes in phyllosphere and endophytes from surrounding soil and air (Finkel et al., 2017). The beneficial microbiome present in the plants is a key indicator of plant health as they play a vital role in regulating plant immunity, production of metabolites, nutrient uptake and acquisition, disease, and insect- pest management along with several other functions. The microbial population residing in soil system includes various PGPR, fungi, actinomycetes, algae, yeasts, cyanobacteria, and many more (Manzar et al., 2021). They aid in transforming organic matter into simpler form that can be assimilated by plants. Microbiomes like filamentous fungi and several bacterial species secrete a wide range of secondary metabolites which are crucial for plant growth and phenological responses. Several studies regarding beneficial role of rhizobacteria in invigorating plant growth and developmental responses along with nutrient acquisition through production of many phytohormones like auxin, cytokinins have been made (Kudoyarova et al., 2014; Egamberdieva et al., 2017). Secondary metabolites like trichocarenes, harzianolide, harzianic acid, $\alpha$ - pyrone produced by various Trichoderma species have been reported to promote plant growth (Vinale and Sivasithamparam, 2020). Several rhizospheric and endophytic bacterial species colonizing turmeric rhizomes have been reported to induce growth promotion, disease management, secondary metabolite production and enhancing curcumin content (Kumar et al., 2017). Several bacterial speciesArthrobacter, Bacillus, Rhizobium, Mycobacterium have been found to be associated with roots of soybean (Egamberdieva et al., 2016). Similarly, orchid rhizosphere harbors Mycobacterium species (Tsavkelova et al., 2007) while wheat roots contains Azotobacter, Azospirillum, Mycoplana, and Rahnella. Endophytic fungi Sinorhizobium meliloti isolated from root nodules of $M$. sativa confer drought tolerance (Naya et al., 2007). Several bacterial species have also been reported to mediate drought tolerance in several species (Chen et al., 2017; Naseem et al., 2018; Ullah et al., 2019). In maize, Leifsonia sp. and Bacillus sp. induced cadmium tolerance thereby increasing root and shoot growth (Ahmad et al., 2016). Several mycorrhizal and endophytic organisms are known to be associated with plants viz., cereals, pulses, oilseeds which enhance their nutritional status (Bhattacharyya et al., 2016).

Anabaena species, Calothrix species, Chlorella fusca acts as biocontrol agent against plant pathogens in many plant species (Prasanna et al., 2008, 2013; Chaudhary et al., 2012; Lee et al., 2016, 2017; Kim et al., 2018). The algal species also provide protection to plants against nematode infection (Khan et al.,
2005, 2007; Hamouda and El-Ansary, 2017). Cyanobacteria increases plant growth and yield by acting as biofertilizer. Species including A. variabilis, Calothrix sp., Hapalosiphon sp., and Nostoc sp. are used as biofertilizers in many crops which increases plant growth and yield (Singh and Datta, 2007; Innok et al., 2009; Karthikeyan et al., 2009). Algal biofertilizers like Nostoc sp., Anabaena sp., fixes atmospheric nitrogen in rice. They also influences soil porosity and soil aggregation. Anabaena azollae is used as a green manure (Vaishampayan et al., 2001). Algal species also provide abiotic stress tolerance in the plants. Scytonema hofmanni provides salt tolerance in the rice (Rodríguez et al., 2006). Chlorella fusca and Chlorella strains (ABC001 \& HS2) delays plant senescence in Erinus alpinus (Lee et al., 2020). Furthermore, several evidences of abiotic stress tolerance by algal communities in the plant species has been reported ( $\mathrm{Li}$ et al., 2014; Arroussi et al., 2018; Lee and Ryu, 2021). Algae are efficient bioremediator of heavy metals in the plants through process of bioaccumulation and biosorption. Species like $C$. vulgaris, Desmodesmus pleiomorphus, Ulva reticulata Cladophora fascicularis Spirogyra insignis are efficiently used to remove heavy metals like Cd, Zn, Cu (Hassan et al., 2017). Algal communities are efficient drivers of $\mathrm{CO}_{2}$ in global carbon cycle and also a better alternative to sequester greenhouse gases biologically (Tsai et al., 2017). Besides this, algal communities also produce plant growth promoting phytohormones and polysaccharides which increases plants growth (Lee and Ryu, 2021). Blue green algae and other algal species like Anabaena, Chrococcus, Oscillatoria, Phormidium are associated with rice, fix atmospheric nitrogen and accelerate nutrient acquisition in plants (Hasan, 2013; Bhattacharyya et al., 2016). Microbial consortia play major role in plant defense mechanism (Xu et al., 2011; Jain et al., 2012; Sarma et al., 2015). Microbial consortium including Pseudomonas, Rhizobium, and Trichoderma species studied in different species are efficient means of plant growth promotion and pathogen tolerance (Alizadeh et al., 2013; Table 2). Rhizobacteria and rhizofungi have an immense beneficial role against insect herbivores besides improving plant health by regulating signaling of defense hormones, secondary metabolite production and synthesis of defense related proteins and enzymes (Rashid and Chung, 2017; Table 3).

\section{Factors Involved in the Availability of Diverse Microbial Populations}

The plant-microbe association is influenced by several factors which directly or indirectly affects the availability of microbiota in the particular environment. They are mainly phyllospheric, rhizospheric and environmental factors that require understanding of the mechanism of the presence of microorganisms. Table 2 determines various drivers of plantmicrobe interaction that provide knowledge of their existence and diversity in the environment. Plants are living organisms that themselves harbor a wide range of microbial entities like bacteria, fungi, actinomycetes. The presence of these microbiota in the plant is mainly influenced by biotic factors including plant species, root architecture, plant genotype, plant age and developmental stages, and abiotic factors like soil $\mathrm{pH}$, 
TABLE 2 | Studies on plant microbe interaction and their adverse climatic conditions.

\begin{tabular}{|c|c|c|c|}
\hline Microbes & Plant species & Abiotic stress & References \\
\hline S. meliloti & M. sativa & $\begin{array}{l}\text { Drought } \\
\text { tolerance }\end{array}$ & Naya et al., 2007 \\
\hline $\begin{array}{l}\text { Glucoacenatobacter } \\
\text { diazotrophicus }\end{array}$ & Sugarcane & $\begin{array}{l}\text { Drought } \\
\text { tolerance }\end{array}$ & Vargas et al., 2014 \\
\hline $\begin{array}{l}\text { Cellulosimicrobium } \\
\text { cellulans }\end{array}$ & Chili & $\begin{array}{l}\text { Chromium } \\
\text { toxicity } \\
\text { tolerance }\end{array}$ & $\begin{array}{l}\text { Chatterjee et al., } \\
2009\end{array}$ \\
\hline $\begin{array}{l}\text { Pseudomonas sp. } \\
\text { and Bacillus sp. }\end{array}$ & Spinach & $\begin{array}{l}\mathrm{Cd}, \mathrm{Pb}, \mathrm{Zn} \\
\text { toxicity } \\
\text { tolerance }\end{array}$ & Shilev et al., 2019 \\
\hline Pantoea alhagi & Wheat & $\begin{array}{l}\text { Drought } \\
\text { tolerance }\end{array}$ & Chen et al., 2017 \\
\hline $\begin{array}{l}\text { Leifsonia sp. and } \\
\text { Bacillus sp. }\end{array}$ & Maize & $\begin{array}{l}\text { Cd toxicity } \\
\text { tolerance }\end{array}$ & Ahmad et al., 2016 \\
\hline Bacillus aryabhatti & Soybean & $\begin{array}{l}\text { Heat stress } \\
\text { tolerance }\end{array}$ & Park et al., 2017 \\
\hline $\begin{array}{l}\text { Pseudomonas } \\
\text { species S1 }\end{array}$ & Chili & $\begin{array}{l}\text { Drought } \\
\text { tolerance }\end{array}$ & Rolli et al., 2015 \\
\hline Trichoderma species & Chickpea & $\begin{array}{l}\text { As toxicity } \\
\text { tolerance }\end{array}$ & Tripathi et al., 2017 \\
\hline $\begin{array}{l}\text { Varivorax paradoxus } \\
5 \mathrm{C}-2\end{array}$ & Pea & $\begin{array}{l}\text { Salinity } \\
\text { tolerance }\end{array}$ & Wang et al., 2016 \\
\hline $\begin{array}{l}\text { Pseudomonas } \\
\text { flurorescence }\end{array}$ & Rice & Flooding & $\begin{array}{l}\text { Etesami et al., } \\
2014\end{array}$ \\
\hline $\begin{array}{l}\text { Bacillus subtilis, } \\
\text { Arthrobacter species }\end{array}$ & Wheat & $\begin{array}{l}\text { Salinity stress } \\
\text { tolerance }\end{array}$ & $\begin{array}{l}\text { Upadhyay et al., } \\
2012\end{array}$ \\
\hline $\begin{array}{l}\text { Serratia plymuthica, } \\
\text { Stenotrophomonas } \\
\text { rhizophia and } \\
\text { Pseudomonas } \\
\text { fluorescence }\end{array}$ & Cucumis & $\begin{array}{l}\text { Salinity stress } \\
\text { tolerance }\end{array}$ & $\begin{array}{l}\text { Egamberdieva } \\
\text { et al., } 2008\end{array}$ \\
\hline $\begin{array}{l}\text { Bacillus subtilis and } \\
\text { Paenibacillus } \\
\text { illinoinensis }\end{array}$ & Pepper & $\begin{array}{l}\text { Drought } \\
\text { tolerance }\end{array}$ & Vigani et al., 2019 \\
\hline $\begin{array}{l}\text { Aspergillus } \\
\text { fumigatus }\end{array}$ & Soybean & Salt stress & Khan et al., 2011 \\
\hline $\begin{array}{l}\text { Pseudomonas } \\
\text { vancouverensis }\end{array}$ & Tomato & $\begin{array}{l}\text { Chilling stress } \\
\text { tolerance }\end{array}$ & $\begin{array}{l}\text { Subramanian } \\
\text { et al., } 2015\end{array}$ \\
\hline Rhizobium sp. & Sunflower & Drought & Alami et al., 2000 \\
\hline $\begin{array}{l}\text { Pseudomonas } \\
\text { fluorescence }\end{array}$ & Groundnut & $\begin{array}{l}\text { Salinity stress } \\
\text { tolerance }\end{array}$ & $\begin{array}{l}\text { Saravanakumar } \\
\text { and Samiyappan, } \\
2007\end{array}$ \\
\hline Serratia species & Chickpea & $\begin{array}{l}\text { Nutrient stress } \\
\text { tolerance }\end{array}$ & Zaheer et al., 2016 \\
\hline Burkholderia species & Tomato & $\begin{array}{l}\text { Cd toxicity } \\
\text { tolerance }\end{array}$ & $\begin{array}{l}\text { Dourado et al., } \\
2013\end{array}$ \\
\hline $\begin{array}{l}\text { Achromobacter } \\
\text { xylosoxidans }\end{array}$ & Mustard green & $\begin{array}{l}\text { Cu toxicity } \\
\text { tolerance }\end{array}$ & Ma et al., 2008 \\
\hline PGPB & Sorghum & $\begin{array}{l}\text { Cr stress \& heat } \\
\text { stress tolerance }\end{array}$ & Bruno et al., 2020 \\
\hline Cyanobacteria & Arabidopsis & Heat stress & Chua et al., 2020 \\
\hline $\begin{array}{l}\text { Pseudomonas } \\
\text { species and } \\
\text { Acinetobacter } \\
\text { species }\end{array}$ & Barley and oats & Salt stress & Chang et al., 2014 \\
\hline
\end{tabular}

(Continued)
TABLE 2 | Continued

\begin{tabular}{|c|c|c|c|}
\hline Microbes & Plant species & Abiotic stress & References \\
\hline $\begin{array}{l}\text { Microalgae- } \\
\text { cyanobacteria }\end{array}$ & Tomato & Salt stress & $\begin{array}{l}\text { Mutale-joan et al., } \\
2021\end{array}$ \\
\hline $\begin{array}{l}\text { Pseudomonas } \\
\text { frederiksbergensis } \\
\text { Os261 }\end{array}$ & Red pepper & Salt stress & $\begin{array}{l}\text { Chatterjee et al., } \\
2017\end{array}$ \\
\hline Azotobacter & Maize & Drought stress & $\begin{array}{l}\text { Shirinbayan et al., } \\
2019\end{array}$ \\
\hline $\begin{array}{l}\text { Salep gum and } \\
\text { Spirulina platensis }\end{array}$ & Maize & Cd toxicity & $\begin{array}{l}\text { Seifikalhor et al., } \\
2020\end{array}$ \\
\hline Seaweed extract & Cucumber & $\begin{array}{l}\text { Low } \\
\text { temperature } \\
\text { stress }\end{array}$ & $\begin{array}{l}\text { Sarhan and } \\
\text { Ismael, } 2014\end{array}$ \\
\hline Oscillatoria agardhii & Wheat & Drought stress & $\begin{array}{l}\text { Haggag et al., } \\
2018\end{array}$ \\
\hline $\begin{array}{l}\text { Scytonema } \\
\text { hofmanni }\end{array}$ & Rice & Salt stress & $\begin{array}{l}\text { Rodríguez et al., } \\
2006\end{array}$ \\
\hline
\end{tabular}

soil salinity, temperature, seasonal variations, soil moisture, and organic matter (Winkel et al., 1997; Zogg et al., 2010) (Figure 2).

Plant and soil hosts multiple varieties of microbiomes. The environmental factors are key regulators in shaping structure and composition of plant microbiome. Plant associated microbiomes are greatly influenced by genotype $x$ environment interactions (Morella et al., 2020). Particular plant species also imparts some influence on composition of microbiome in rhizosphere. Phyllospheric microbiome is affected by environmental and anthropogenic factors. Environmental factors include irradiation, ozone, animal borne sources, secretion of volatile organic compounds, and health development status of plants, plant genotype and others. Anthropogenic activities which influence microbiome abundance include urbanization, application of fertilizers, pesticides, herbicides, fungicides, biostimulants, and industrialization (Gupta and Patil, 2021). Particular plant species also imparts some influence on composition of microbiome in rhizosphere. Soil associated factors like possible available mineral content in the soil, $\mathrm{pH}$, gas gradient establishes soil microbiome plays key role in shaping diversity of microbiota (Tecon and Or, 2017). Soil properties and geographical locations (altitude, latitude, and longitude), soil moisture content impact structure of microbiomes at great extent (Islam et al., 2020). The structure and composition of plant microbiome can be influenced by climatic factors like UV-radiation, temperature variations, and change in $\mathrm{CO}_{2}$ concentration (Kemble et al., 2014; Wang et al., 2017; Hassani et al., 2018; Yu et al., 2018; Sørensen et al., 2019; Islam et al., 2020).

\section{Effect of Resilient Climate on Microbial Diversity}

Climate change and changing weather patterns is a matter of global concern among researchers and agriculturalists now-adays. Climate change is undeniable phenomena which occurs 
TABLE 3 | Role of beneficial microbe in plant defense.

\begin{tabular}{|c|c|c|c|}
\hline $\begin{array}{l}\text { Beneficial } \\
\text { microbes }\end{array}$ & $\begin{array}{l}\text { Biotic stress } \\
\text { causing } \\
\text { microbes }\end{array}$ & Host plants & Reference \\
\hline $\begin{array}{l}\text { Bacillus subtilis } \\
\text { FB17 }\end{array}$ & $\begin{array}{l}\text { P. syringae pv. } \\
\text { tomato }\end{array}$ & Tomato & $\begin{array}{l}\text { Rudrappa et al., } \\
2008\end{array}$ \\
\hline $\begin{array}{l}\text { Rhizospheric } \\
\text { microbes }\end{array}$ & M. oryzae & Rice & $\begin{array}{l}\text { Spence et al., } \\
2014\end{array}$ \\
\hline PGPR & Fusarium sp. & Potato & Recep et al., 2009 \\
\hline $\begin{array}{l}\text { PGPR and } \\
\text { Trichoderma } \\
\text { koningiopsis }\end{array}$ & Fusarium & $\begin{array}{l}\text { Cape } \\
\text { gooseberry }\end{array}$ & Díaz et al., 2013 \\
\hline Pseudomonas & $\begin{array}{l}\text { Phytophthora } \\
\text { infestans }\end{array}$ & Potato & $\begin{array}{l}\text { de Vrieze et al., } \\
2018\end{array}$ \\
\hline $\begin{array}{l}\text { T. harzianum Tr6 \& } \\
\text { Pseudomonas sp. } \\
\text { Ps14 }\end{array}$ & $\begin{array}{l}\text { Fusarium } \\
\text { oxysporum } f . \text { sp. } \\
\text { radicis } \\
\text { cucumerinum }\end{array}$ & Cucumber & $\begin{array}{l}\text { Alizadeh et al., } \\
2013\end{array}$ \\
\hline $\begin{array}{l}\text { Pseudomonas } \\
\text { fluorescence }\end{array}$ & Leaf folder pest & Rice & $\begin{array}{l}\text { Saravanakumar } \\
\text { et al., } 2008\end{array}$ \\
\hline $\begin{array}{l}\text { Stenotrophomonas } \\
\text { sp., Xanthomonas } \\
\text { sp., Microbacterium } \\
\text { sp }\end{array}$ & $\begin{array}{l}\text { Hyaloperonospora } \\
\text { arabidopsis }\end{array}$ & Arabidopsis & $\begin{array}{l}\text { Liu and Brettell, } \\
2019\end{array}$ \\
\hline $\begin{array}{l}\text { Bacillus subtilis and } \\
\text { Bacillus } \\
\text { amyloliquefaciens }\end{array}$ & Botrytis cinerea & Tobacco & Cawoy et al., 2014 \\
\hline $\begin{array}{l}\text { Saccharothrix } \\
\text { yanglingenesis }\end{array}$ & $\begin{array}{l}\text { P. synringae pv. } \\
\text { tomato DC } 3000\end{array}$ & Arabidopsis & Zhang et al., 2018 \\
\hline $\begin{array}{l}\text { Rhizobium etli strain } \\
\text { G12 }\end{array}$ & $\begin{array}{l}\text { Aphis gossypii } \\
\text { Glover }\end{array}$ & Squash & $\begin{array}{l}\text { Martinuz et al., } \\
2012\end{array}$ \\
\hline $\begin{array}{l}\text { Trichoderma virens, } \\
\text { T. atroviridae }\end{array}$ & $\begin{array}{l}\text { Alternaria solani, } \\
\text { Botrytis cinerea, P. } \\
\text { syringae }\end{array}$ & Tomato & $\begin{array}{l}\text { Salas-Marina } \\
\text { et al., } 2015\end{array}$ \\
\hline $\begin{array}{l}\text { Pseudomonas } \\
\text { PHU094, } \\
\text { Trichoderma THU } \\
\text { 0816, Rhizobium } \\
\text { R2091 }\end{array}$ & Sclerotium rolfsii & Chickpea & Singh et al., 2013 \\
\hline $\begin{array}{l}\text { Anabaena varialilis, } \\
\text { Anabaena torulosa, } \\
\text { Anaebaena laxa, } \\
\text { Calothrix sp. }\end{array}$ & $\begin{array}{l}\text { Pythium } \\
\text { debaryanum, } \\
\text { Fusarium } \\
\text { oxysporum, F. } \\
\text { moniliforme, } \\
\text { Rhizoctonia solani }\end{array}$ & Tomato, cotton & $\begin{array}{l}\text { Prasanna et al., } \\
\text { 2008, 2013; } \\
\text { Chaudhary et al., } \\
\text { 2012; Lee and } \\
\text { Ryu, } 2021\end{array}$ \\
\hline Pseudomonas sp. & Rhizoctonia solani & Tomato & $\begin{array}{l}\text { Pandey and } \\
\text { Gupta, } 2020\end{array}$ \\
\hline Trichoderma sp. & $\begin{array}{l}\text { Botrytis cinerea } \\
\text { and Leptosphaeria } \\
\text { maculans }\end{array}$ & Tomato, canola & $\begin{array}{l}\text { Vinale et al., } \\
2008 a, b\end{array}$ \\
\hline $\begin{array}{l}\text { Pseudomonas } \\
\text { fluorescence }\end{array}$ & Desmia funeralis & Rice & $\begin{array}{l}\text { Karthiba et al., } \\
2010\end{array}$ \\
\hline $\begin{array}{l}\text { P. fluorescence Pf1, } \\
\text { B. subtilis, T. viridae }\end{array}$ & $\begin{array}{l}\text { Lasiodiplodia } \\
\text { michiganensis }\end{array}$ & Tuberose & $\begin{array}{l}\text { Durgadevi et al., } \\
2018\end{array}$ \\
\hline $\begin{array}{l}\text { B. subtilis MB1600 \& } \\
\text { R. tropicium R1899 }\end{array}$ & $\begin{array}{l}\text { Fusarium solani } f . \\
\text { sp. phaseoli }\end{array}$ & Common bean & $\begin{array}{l}\text { Estevez de Jensen } \\
\text { et al., } 2002\end{array}$ \\
\hline B. amyloliquefaciens & $\begin{array}{l}\text { Peronophythora } \\
\text { litchii }\end{array}$ & Litchi & Wu et al., 2017 \\
\hline
\end{tabular}

(Continued)
TABLE 3 | Continued

\begin{tabular}{|c|c|c|c|}
\hline $\begin{array}{l}\text { Beneficial } \\
\text { microbes }\end{array}$ & $\begin{array}{l}\text { Biotic stress } \\
\text { causing } \\
\text { microbes }\end{array}$ & Host plants & Reference \\
\hline Ulva armoricana & $\begin{array}{l}\text { Erysiphepolygoni, } \\
\text { Erysiphe necator } \\
\text { and Sphareotheca } \\
\text { fuliginea }\end{array}$ & $\begin{array}{l}\text { Bean, } \\
\text { grapevine, and } \\
\text { cucumber }\end{array}$ & $\begin{array}{l}\text { Jaulneau et al., } \\
2011\end{array}$ \\
\hline $\begin{array}{l}\text { Cystoseira } \\
\text { myriophylloides and } \\
\text { Fucus spiralis }\end{array}$ & $\begin{array}{l}\text { Agrobacterium } \\
\text { tumefaciens }\end{array}$ & Tomato & Esserti et al., 2016 \\
\hline Trichoderma species & $\begin{array}{l}\text { Alternaria species } \\
\text { and Fusarium } \\
\text { species }\end{array}$ & $\begin{array}{l}\text { Vegetables and } \\
\text { crops }\end{array}$ & Meena et al., 2017 \\
\hline $\begin{array}{l}\text { Spatoglossum } \\
\text { variabile, Stokeyia } \\
\text { indica, and } \\
\text { Melanothamnus } \\
\text { afaqhusainii }\end{array}$ & Meloidogyne spp. & $\begin{array}{l}\text { Watermelon } \\
\text { and egg plant }\end{array}$ & Baloch et al., 2013 \\
\hline $\begin{array}{l}\text { Oscillatoria, } \\
\text { Anabaena, Nostoc, } \\
\text { Nodularia, and } \\
\text { Calothrix species }\end{array}$ & $\begin{array}{l}\text { Alternaria alternate } \\
\text { and Botrytis } \\
\text { cinerea }\end{array}$ & Pepper & Kim, 2006 \\
\hline
\end{tabular}

mainly due to anthropogenic activities including the factors like greenhouse effect, deforestation, urbanization, global warming. Other crucial factors includes fossil fuels combustion, increase livestock farming, excessive use of fertilizers, nitrous oxide emissions, increasing incidence of different abiotic, and biotic stresses. The global warming associated with climate change along with elevated temperature, $\mathrm{CO}_{2}$ levels, changing rainfall patterns impart a significant impact on plant developmental patterns and their physiology. However, microbial diversity and its nature activities have not been spared in the inevitable changing climatic conditions. They are microscopic, diverse, and present abundantly in marine, terrestrial and agricultural ecosystem. It is well-known fact that microbiota are efficient players in the carbon and nutrient cycling process, a key mediator to plant health, and play a crucial role in agricultural production. The study of the effect of the resilient climate in microfauna is limited and requires greater attention. Being ubiquitous, microorganisms affect climate change in marine, terrestrial and agricultural ecosystems (Bastiaansen et al., 2020). The ecosystem is influenced by changes in temperature, rainfall patterns, and stress conditions (drought, salinity, ozone stress, pathogens.). Changes in climate durability and seasonal abnormalities possess a great impact on the structural and diversity of microbial communities either directly or when they are associated with plants. The drivers of changing climatic conditions causes shifting of microbial community from particular ecosystem which further impart negative effect in its function. Global warming has direct impact on microbial respiration. Warming alters composition of microbial population (Classen et al., 2015). However, temperature, $\mathrm{CO}_{2}$, and other environmental factors play an important part in regulating the diversity of microbial 


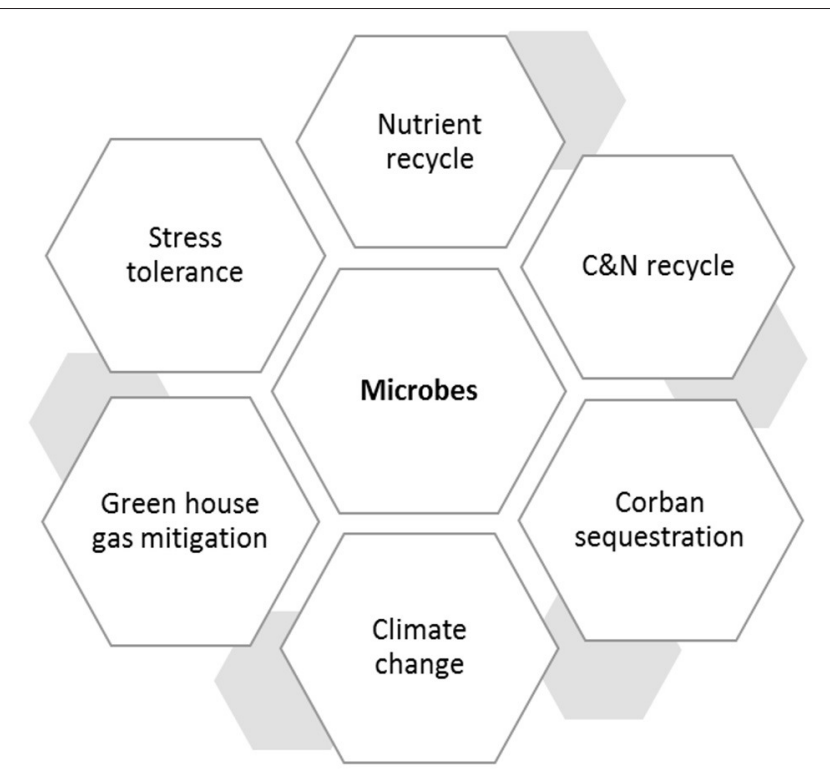

FIGURE 2 | Role of microbes in different aspects of climatic phenomena.

community both above and below ground level. The microbial populations are often associated with rhizosphere and gets influenced by soil and exudates secreted by roots.

\section{Effect of Temperature on Plant-Microbe Interaction}

Temperature is the fundamental factor that is decisive in plant growth and phenological characteristics, along with the distribution and occurrence of a particular microbial population in the community (Angilletta, 2009; Kashyap et al., 2017). The increase in human interventions and the emission of GHGs like $\mathrm{CO}_{2}$, water vapor, methane leads to the rise in average global temperature in the past few decades. It is expected that the average temperature is going to increase by $1.8-3.6^{\circ} \mathrm{C}$ by the year 2100 , which may lead to water deficiency and drought in many parts of the world (Compant et al., 2010). The increase in average temperature influences the activity and morphology of plants. Several studies have been made regarding the demonstration of the potential effect of elevated temperature on different crop species (Chen et al., 2021). The increased average temperature imparts a potential market effect on the composition, activities and occurrence of plant-associated microbial communities. An elevated temperature may result in faster growth of microorganisms with altered respiration. Similarly, elevated temperature and drought conditions significantly affect plantmicrobe association, activity and abundance. Global warming and elevated temperature conditions have a direct influence on microbial respiration rates present in the rhizosphere (Classen et al., 2015). Studies show that soil respiration performed by microbial community increases exponentially with temperature (Karhu et al., 2014). Frey et al. (2013) found that the utilization of organic matter by soil microbes is temperature-dependent. The changing climatic conditions, the pathogenicity of microorganisms can also be correlated with temperature alterations, $\mathrm{CO}_{2}$ concentration and other environmental conditions (Vela'squez et al., 2018). Soil warming and drought conditions pose an indirect impact on plant nutrient uptake and carbohydrate exchange in the rhizosphere by arbuscular mycorrhizal fungi (AFM) (Newsham et al., 1995). Glomus intraradices and Glomus mossae showed increased growth and colonization with temperature (Monz et al., 1994). Elevated temperature increases the virulence of bacteria Pectobacterium atrosepticum causing soft rot and certain other seed born microbes that promoted degradation of cell wall enzyme and increase disease incidence in plants (Hasegawa et al., 2005). Ocean warming due to elevated temperature results in phonological shifts in sea weeds globally (de Bettignies et al., 2018). Elevated temperature adversely influences the activity of coralline algae (Page et al., 2021). Studies conducted reveals that elevated temperature has considerable effects on cyanobacterial growth and development (Deng et al., 2021). Increased temperature coupled with heat waves as consequences of global warming enhances the activity of microbial community able to mineralize microbial necromass, recycling $\mathrm{C}$ and $\mathrm{N}$ and thus, amplify warming effects in mountainous soil (Donhauser et al., 2020).

Similarly, Wang et al. (2020) also reported the increased microbial necromass nitrogen and microbial turnover in the soil with temperature. However, other environmental conditions, like moisture and UV radiation, also influence microbe survival and growth. Low moisture availability and drought conditions affect the microbial population in the soil, root endosphere and rhizospheric conditions (Cheng et al., 2019). Xu et al. (2018) studied that drought conditions reduce bacterial population in rhizosphere and root endosphere in sorghum root microbiome. Drought conditions decrease AMF colonization. AMF could not colonize plant under drought (Schellenbaum et al., 1998; Staddon et al., 2004). However, a comparative study performed by Querejeta et al. (2009) reveals that ectomycorrhiza has reduced colonization ability in oak under drought than AMF deciphering the fact that colonization by AMF under water-scarce conditions are more desirable for future climatic scenarios.

\section{Effect of $\mathrm{CO}_{2}$ on Plant-Microbe Interaction}

The atmospheric $\mathrm{CO}_{2}$ is very crucial in regulating carbon allocation and composition of root exudates in the soil environment, which imparts a potential effect on the rhizospheric environment with beneficial microbes (Berendsen et al., 2012; Williams et al., 2018). Microbes play a vital role in net carbon exchange through various ways, viz. respiration and decomposition of organic matter, pathogenic or symbiotic association with plants, and by altering the nutrient status of the soil. Elevated $\mathrm{CO}_{2}$ levels alter plant physiology and metabolism and also stimulate direct and indirect effect on the microbial community in rhizospheric and phyllospheric conditions. The elevated $\mathrm{CO}_{2}$ levels often lead to reshaping the root exudates composition along with alterations in nutrient availability (Ostle, 2008; Compant et al., 2010). Microbes like fungi consist of higher carbon assimilation efficiency than bacteria and have more significant potential to store carbon than mobilization. Thus, 
an increase in the carbon emission through roots by plants stimulates the growth in the microbial population in the soil system, thereby reducing soil nitrogen i.e., available for the plant due to soil nitrogen immobilization.

The elevated $\mathrm{CO}_{2}$ level in the atmosphere often results in increased soil respiration (Korner and Arnone, 1992; Hungate et al., 1997). The soil environment contains a higher proportion of $\mathrm{CO}_{2}$ than the atmosphere. Microbes such as fungi, bacteria, actinomycetes show variable responses to elevated $\mathrm{CO}_{2}$ conditions. In Pisum sativum cv. Solara, Gavito et al. (2000) observed no significant effect of elevated $\mathrm{CO}_{2}(700 \mathrm{ppm})$ on the colonization of arbuscular mycorrhizal fungi (AMF) while in Barnyad grass, elevated $\mathrm{CO}_{2}(7 \mathrm{ppm})$ showed a significant increase in mycorrhizal colonization with an increase in $\mathrm{N}$ and $\mathrm{P}$ uptake (Tang et al., 2009). A study conducted using 18s RNA sequencing-based Illumina Miseq technique indicated that long term exposure to elevated $\mathrm{CO}_{2}$ (550 ppm) significantly reduces the presence of Claroideoglomus and Glomus species in paddy in sub-humid tropical conditions (Panneerselvam et al., 2020). Similarly, the ectomycorrhizal communities also get influenced by changing $\mathrm{CO}_{2}$ levels in the atmosphere. Godbold and Berntson (1997) observed the increased colonization of ECM in Boswellia papyrifera and Pinus strobus under elevated $\mathrm{CO}_{2}$ conditions $(700 \mathrm{ppm})$. Similarly, Fransson et al. (2005) demonstrated a three-fold increase in biomass of ECM mycelia in P. sylvestris in high $\mathrm{CO}_{2}$ conditions. Besides AMF and ECM, Plant Growth Promoting Bacteria (PGPB) have also been found to support plant growth. Several organisms that belong to this genera include Arthrobacter, Azospirillum, Azotobacter, Bacillus, Erwnia, Proteus, Pseudomonas, Rhizobium, etc. Bacterial communities associated with the plant biome also have a significant effect on $\mathrm{eCO}_{2}$ levels. Studies conducted in FACE conditions (Free-air $\mathrm{CO}_{2}$ enrichment) demonstrated that elevated $\mathrm{CO}_{2}(600 \mathrm{ppm})$ causes a substantial increase in the population of $R$. leguminosarum bv. trifolli in the rhizosphere of white clover (Schortemeyer et al., 1996).

Numerous studies have been made regarding the influence of $\mathrm{eCO}_{2}$ in plant growth promoting bacteria communities in several species (Lipson et al., 2006; Haase et al., 2007; Lesaulnier et al., 2008; $\mathrm{Xu}$ et al., 2013). Increase in $\mathrm{CO}_{2}$ concentration in the atmosphere also influences the microbial community in the oceanic environment. The growth and survival of seaweeds in high $\mathrm{CO}_{2}$ environment is tempting as seaweeds are benefitted from increased organic carbon concentration (Harley et al., 2012). Recent developments in algal research determine that with increased $\mathrm{CO}_{2}$ concentration the biomass and lipid in microalgae species also increased (Singh and Singh, 2014). Thus, elevated $\mathrm{CO}_{2}$ conditions influence microbial communities, biological system of plants and thereby play vital role in future climatic conditions. Elevated $\mathrm{CO}_{2}$ level may alter activities of soil microorganisms involved in nutrient acquisition (Haase et al., 2007), influences pathogenic responses of the plants (YáñezLópez et al., 2012) and help soil carbon sequestration. Moreover, the role of rhizospheric microorganisms under elevated $\mathrm{CO}_{2}$ level is needed to be assessed for climate-resilient agriculture along with rigorous effort in scaling up to explore the long term effect of soil microbes to increased $\mathrm{CO}_{2}$ conditions and efficient carbon sequestration by plant-microbe interaction (Malmstrom and Field, 1997; Grover et al., 2015).

\section{Other Factors Influencing Plant-Microbe Interaction}

The inconsistent climatic conditions possess considerable impact on structure, function and diversity of plant- microbe association in the environment (Dastogeer et al., 2020). Increased climatic conditions result in the increased exposure of radiations to plants which also modify ozone dynamics in the atmosphere. It is well-known that increased UV-radiations deplete stratospheric ozone content in the atmosphere, thus alters climate. These alterations have adverse effects on the plants and associated microbiome. Increasing UV-radiations changes cell oxygen yield, photosynthetic system, and growth of cyanobacteria (Zeeshan and Prasad, 2009). However, lichens have not much considerable effects of UV-B radiations (Bjerke et al., 2005). Radiation sensitive fungi possess reduced growth as infrared radiations induces damage to cell proliferation rate. The UV radiations have adverse effect on conidial germination, hyphal growth and chemical production (Braga et al., 2015; Thind and Schilder, 2018). Similarly, it negatively affects growth and survival of bacterial communities (Vanhaelewyn et al., 2020).

The phyllospheric communities are relatively more affected to increased radiations as rhizospheric communities and are attributed to frequent and drastic changes with change in climatic conditions. The change in climatic conditions results in increased incidence of stresses in the environment. Climate change increases the activities of pathogens and heterotrophic microorganisms, shifting of beneficial microbes from one ecological niche to another. Precipitation is an important regulator of activities of plant and microbiomes. Adequate precipitation increases the activity of soil microbes' hence increasing microbial biomass carbon. The phyllospheric biomass can be positively correlated with belowground microbial biomass carbon in response to adequate precipitation (Zhang and $\mathrm{Xi}$, 2021). Global warming and climatic aberrations potentially cause drought stress. The scarcity of water in the rhizospheric region reduces mycorrhizal mycelium formation in the plant roots (Singh et al., 2019). It is evident there are multiple drivers of plant microbiota association aboveground and belowground communities. They regulate the structure and activities of microbes and also have considerable influence on plant system.

\section{Role of Microbes in Climate Resilience}

Microbes are the diverse and ubiquitous organisms present on the earth's surface. Plants themselves consist of a wide range of microbial niches present in them and the soil ecosystem. Microbes are well-known to perform various ecological functions in nature. They regulate the concentration of greenhouse gases and influence radiative force. The microbiota may impact either positive or negative feedback on climate resilience. Several microbial species plays vital role in carbon sequestration, carbon mineralization and reduces the emission of greenhouse gases viz. $\mathrm{CO}_{2}, \mathrm{CH}_{4}, \mathrm{~N}_{2} \mathrm{O}$ (Singh et al., 2010) in the terrestrial ecosystem. Climate change has a potential effect on soil microbial biomass, organic matter decomposition, net primary production, 
TABLE 4 | Role of microbes in plant physiological responses.

\begin{tabular}{|c|c|c|c|}
\hline Microbes & $\begin{array}{l}\text { Physiological } \\
\text { trait } \\
\text { specifications }\end{array}$ & Host plants & References \\
\hline $\begin{array}{l}\text { Rhizobium } \\
\text { species, } \\
\text { Azotobacter }\end{array}$ & $\begin{array}{l}\text { Fixation of } \\
\text { atmospheric } \\
\text { nitrogen }\end{array}$ & Soybean & $\begin{array}{l}\text { Naamala et al., 2016; } \\
\text { Naamala and Smith, } \\
2020\end{array}$ \\
\hline $\begin{array}{l}\text { AM fungi \& } \\
\text { PGPR }\end{array}$ & $\begin{array}{l}\text { Increased } \\
\text { antioxidant } \\
\text { activities, } \\
\text { flavonoid, and } \\
\text { phenol content }\end{array}$ & Turmeric & Dutta and Neog, 2016 \\
\hline $\begin{array}{l}\text { Endophytic \& } \\
\text { Rhizospheric } \\
\text { bacteria }\end{array}$ & $\begin{array}{l}\text { Stimulates plant } \\
\text { growth, secondary } \\
\text { metabolite } \\
\text { production, } \\
\text { enhanced } \\
\text { curcumin content }\end{array}$ & Turmeric & Kumar et al., 2017 \\
\hline $\begin{array}{l}\text { Root colonizing } \\
\text { microbes }\end{array}$ & $\begin{array}{l}\text { Stimulates root } \\
\text { development }\end{array}$ & Arabidopsis & $\begin{array}{l}\text { Verbon and Liberman, } \\
2016\end{array}$ \\
\hline $\begin{array}{l}\text { Bacillus } \\
\text { anthracis \& B. } \\
\text { thuringenisis }\end{array}$ & Improved growth & Wheat & Paul et al., 2020 \\
\hline $\begin{array}{l}\text { Streptomyces } \\
\text { sp. }\end{array}$ & $\begin{array}{l}\text { Plant growth } \\
\text { promoting } \\
\text { activities }\end{array}$ & $\begin{array}{l}\text { Grapevine, } \\
\text { wheat }\end{array}$ & $\begin{array}{l}\text { Couillerot et al., 2013; } \\
\text { Toumatia et al., } 2016\end{array}$ \\
\hline $\begin{array}{l}\text { Bacillus cereus } \\
\text { N5 }\end{array}$ & $\begin{array}{l}\text { Siderophore } \\
\text { production, } \\
\text { phosphate } \\
\text { solubilization }\end{array}$ & Maize & Abedinzadeh et al., 2018 \\
\hline $\begin{array}{l}\text { Burkholderia } \\
\text { phytofirmans }\end{array}$ & $\begin{array}{l}\text { Promotes IAA } \\
\text { synthesis \& ACC } \\
\text { deaminase activity }\end{array}$ & $\begin{array}{l}\text { Potato, tomato, } \\
\text { onion, maize, } \\
\text { barley }\end{array}$ & Weilharter et al., 2011 \\
\hline PGPB & $\begin{array}{l}\text { Growth promotion, } \\
\text { enhanced root and } \\
\text { shoot biomass, } \\
\text { plant nutrient } \\
\text { status, and } \\
\text { nutrient use } \\
\text { efficiency }\end{array}$ & Sugarcane & Cipriano et al., 2021 \\
\hline $\begin{array}{l}\text { Endophytic } \\
\text { bacteria }\end{array}$ & $\begin{array}{l}\text { Promotes growth, } \\
\text { hormone } \\
\text { modulation, } \\
\mathrm{N} \text {-fixation, } \\
\text { siderophore } \\
\text { production }\end{array}$ & Rice & Walitang et al., 2017 \\
\hline $\begin{array}{l}\text { B. } \\
\text { amyloliquifaciens }\end{array}$ & $\begin{array}{l}\text { Production of } \\
\text { gibberellic acid }\end{array}$ & Rice & Shahzad et al., 2016 \\
\hline $\begin{array}{l}\text { Trichoderma } \\
\text { sp. }\end{array}$ & $\begin{array}{l}\text { Production of } \\
\text { secondary } \\
\text { metabolites }\end{array}$ & Maize & Mukherjee et al., 2018 \\
\hline
\end{tabular}

nutrient cycle, vegetation and precipitation, on local and global regimes. However, numerous significant studies have been made regarding the role of microbiota in environmental changes (Table 4).

Crop growth and productivity are directly related to changes in environmental conditions and climate vulnerability, and the role of beneficial microbes in alleviating climatic abnormalities is well-established by various studies (Carrio'n et al., 2019; de Souza et al., 2020). Abiotic and biotic stresses are one of the significant consequences of climate abnormalities and are major constraints in crop production and plant growth. The presence of microbial population in or within the plants alleviates the harmful effects of stresses and possesses synergistic effects with the plant and the environment (Naylor et al., 2017; Compant et al., 2019). The phenomenon of global warming and greenhouse gases emission are parallely correlated, which ultimately stimulates climate change. As we know, this phenomenon directly or indirectly affects the microbial population and community in the rhizospheric and phyllospheric biome. Temperature elevation due to greenhouse gases emission increases respiration, fermentation and methanogenesis of the microbial community. Microbes like bacteria, fungi, actinomycetes are efficient in decomposing organic matter, which further stimulates global warming in the environment and $\mathrm{CO}_{2}$ flux in the atmosphere (Abatenh et al., 2018). Microbial communities influence the biogeochemical cycle, nutrient cycling, carbon, and methane cycle status in the atmosphere (Abatenh et al., 2018). Microbial respiration is a crucial pathway for carbon efflux which aids in emission of carbon dioxide naturally. Methanotrophs play an important part as a biological sink to mitigate methane emission in the atmosphere. Several species of algal communities Oscillatoria, Nostoc, Anabaena has potential role in combating stress conditions in different plant species. Phytomicrobiome also contributes to global food security by determining crop yield and climate resiliency. Climate change mitigation is a necessary measure that can be achieved by adopting several measures. The use of biofertilizers which are composed of microorganisms like bacteria, fungi can be an efficient alternative to chemical fertilizers, similarly, biofuels instead of fossil fuels. Soil contains plenty of microorganisms. Soil harboring microbes play an essential role in nutrient cycling, resistance to soil-borne pathogens and changing climatic conditions.

\section{Interplay of Hormonal Crosstalk With Plant-Microbe Interactions Under Changing Climatic Conditions}

Plant hormones are organic substances produced in minute quantity which stimulate plant physiological processes. They are the key regulators of plant growth and development in response to external environmental conditions. Plants synthesize various hormones which regulate their metabolism and development. They can be either growth promoters like auxins, gibberellins, cytokinins, or growth inhibitors like ABA. They are chemical messengers which are inevitable for controlling cellular activities and plant metabolic responses. Climate change causes invigoration of various stress responses in plants like drought, salinity and heavy metals toxicity, the incidence of pests and diseases and pathogen attack. These abiotic and biotic stresses are potential threats to agricultural production and food security worldwide. Besides this, these climatic calamities alter plant physiological processes and impart negative effect on plant metabolism and functioning. Although plant impose several tolerance mechanism and pathways to avoid the potential effect of stress conditions when stress conditions prevail. Phytohormones are important growth regulators which 
are inevitable for plant growth and provide a defense to plant under stress conditions. Studies revealed that the application of phytohormones under stress improves plant growth and metabolism. Auxins and ABA are key regulators in abiotic stress tolerance (Hu et al., 2013). The negative effect of Pb on sunflower was mitigated by a low auxin concentration with increased root growth. Phytohormones play crucial role in alleviating stress tolerance in plants. Seed priming with auxin alleviates abiotic stress in many crop species (Rhaman et al., 2021).

Similar to auxins, the potential role of other phytohormones has also been deciphered in several studies (Singh et al., 2013; Singh and Singh, 2017; Sharma et al., 2019). The interplay of hormonal activities has also been demonstrated in biotic stresses in plants. Plant growth regulators control the defense mechanism of the plants and induce tolerance to diseases causing pathogens, insect-pest and herbivory. The key hormones regulating plant defense responses include Jasmonic acid (JA), Salicylic acid (SA), which have been widely studied in plant immunity (Aerts et al., 2020). When pathogen invasion prevails in the plant system, the latter consists certain immune response to the plants. The existing procedure of defense utilizes pattern recognition receptors (PRRs), which exists on the surface of plant cells, to detect certain patterns, possibly known as pathogen-/microbe-associated molecular patterns (PAMPs/MAMPs). PAMPs/MAMPs trigger pattern-triggered immunity (PTI) in the plants, which restricts pathogen attack.

However, another mechanism of resistance effector-triggered (ETI) immunity functions in response to pathogen attack (Figure 1). Additionally, the plant has also developed intracellular resistance to counteract pathogen attack via the establishment of R-proteins, which stimulates ETI to develop defense responses in plants. Defense mechanism (PTI \& ETI) induces certain responses against pathogen infection in plant parts, including necrotic lesions at the infected site to cease pathogen movement, increase in $\mathrm{Ca}^{2+}$ concentration inside the cell, stimulation of MAPKs, defense-related proteins (e.g., PR-1, $\beta$ 1,3- glucanase, chitinases, ribonuclease like defensin etc.), production of phytoalexins and antimicrobial components (Checker et al., 2018). Furthermore, the activation of certain phytohormones like SA, JA, ethylene, gibberellins, brassinosteroids, auxins etc. have also been implicated in conferring defense mechanism against biotic stresses. The signaling crosstalk of these hormones, either synergistically or antagonistically, plays a fundamental role in the defense mechanism in plants. The signaling of the SA is crucial for defense against biotrophic pathogens, whereas the JA signaling is essential for controlling necrotrophic pathogens (Shigenaga et al., 2017). Activation of jasmonate and ethylene together stimulates the induction of plant defense in Arabidopsis against Alternaria brassicola; however antagonism of hormone ABA-CK that modulates resistance in tobacco against Pseudomonas syringae (Penninckx et al., 1998). Similar studies of hormone crosstalk have been conducted in different plant species against various pathogenic responses (Naseem et al., 2012; Piisila et al., 2015).

Plant hormones thus play a significant role in stimulating stress tolerance by modulation of genes, downstream signaling by $\mathrm{Ca}^{2+}$ sensors, involving G-proteins signaling, ABA-mediated stress responses; thereby maintaining homeostasis and plant adaptation to environmental challenges and climatic abnormalities ( $\mathrm{Ku}$ et al., 2018). Microbial communities are key regulators of stress tolerance under changing climatic perturbations. Studies conducted regarding the potential role of microbial populations in ameliorating stress conditions are evident for few decades. Plant beneficial microbes play a significant role in mitigating stress conditions in plants by implicating several mechanisms (Forni et al., 2017; Figure 1). Plant hormones widely influence the microbial colony associated with the plants (Foo et al., 2019). The rhizospheric region of plant system harbors a wide variety of microbial population that participates in plant growth and development by secretion of various polysaccharides, metabolites, and hormones. Root associated microbes stimulate mitigation of salt stress and osmotic stress by the production of phytohormones (Yandigeri et al., 2012).

PGPR provides considerable protection to plants under abiotic and biotic stress responses by inducing phytohormone signaling and activating defense responses (Shilev et al., 2019; Khan et al., 2020; Kashyap et al., 2021). Thus, it is now evident that phytohormones have a positive role in increasing plant stress tolerance in changing climatic scenario. Microbial mediated phytohormones production and stimulation influences not only rhizospheric growth but also alleviates abiotic and biotic stress tolerance concurring plant life cycle. Further studies are required to identify the phytohormone modulation in plant tissues by the microbial population under stress response. Also, the identification of receptors and transcription factors are needed to identify the gene expression after microbial phytohormone application. Hormonal crosstalk and signaling mechanism of microbial communities like PGPR and plant growth promoting fungus in nutrient acquisition in the plant requires more attention. The role of biotechnological approaches in plantmicrobe hormonal crosstalk under stress conditions warrants a thorough investigation.

\section{Approaches}

Now-a-days, climate change is globally increasing. It is a prevalent phenomenon that affects the demand for food supply to a growing population, thereby affecting global food security. The major consequence of climate change includes the increased concentration of $\mathrm{CO}_{2}$ in the atmosphere, elevated temperature changing rainfall patterns in various parts of the world (Figure 3). As climatic aberrations are progressing, it may lead to several abiotic stresses and pathogen attack, which is detrimental for crops. Besides, the changing climatic patterns disturb the hydrological cycle and water availability which may also impart a negative impact on agricultural production (Kashyap et al., 2018). Temperature and light alterations decrease the photosynthetic rate, translocation of photosynthates, and increase transpiration. Elevated $\mathrm{CO}_{2}$ concentration also possesses variable effects on different plant species. Also, reduced or excess rainfall altered cell growth, protein synthesis, decreased plant metabolism, and favored pathogens. These climatic conditions have a real effect on plants in the long term. However, the potential effect of altered climatic conditions has been incessantly studied in many 


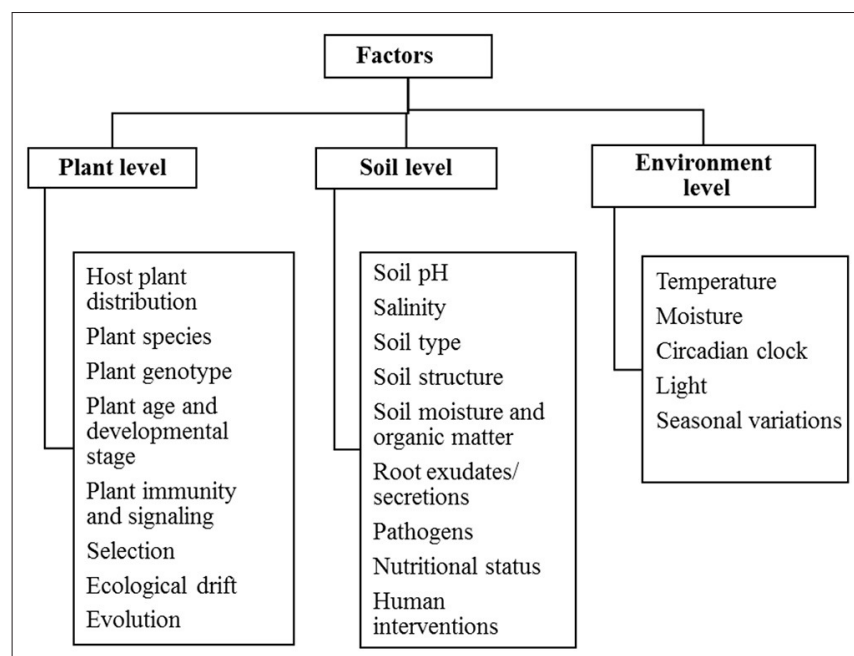

FIGURE 3 | Factors affecting plant-microbe interaction.

crops (De Oliveira et al., 2013; Raza et al., 2019). Climate change has a pronounced effect on soil microbe, plant microbes and their interaction. Microbes regulate a wide range of ecological functions in the plant sand soil ecosystem. The potential impacts of changing climatic conditions have been reviewed extensively in many studies in different species (Classen et al., 2015; Verheijen et al., 2015). Thus, climate change mitigation approaches are a crucial step for environment sustainability, production and provide protection to plant from climatic aberrations. A proper mitigation approach is required to be taken to tackle changing climatic conditions.

Some of the traditional agricultural practices that involve building resilient climate include agroforestry, intercropping, crop rotation, cover cropping, traditional organic composting, which are gaining rounds for mitigation approaches and can be adopted as an alternative method for sustainable agriculture in changing climatic conditions, but modern agricultural practices along with traditional strategies are needed to be addressed (Singh and Singh, 2017). Modern approaches and biotechnological tools for climate change mitigation are acquiring more importance now-a-days. As discussed, greenhouse gases are the main cause of global warming. Biotechnological methods are effective in reducing the emission of greenhouse gases e.g., use of biotechnological methods increases fertilizer efficiency by many folds (Ferrante et al., 2017), enhanced $\mathrm{CO}_{2}$ absorption, thereby increasing photosynthetic efficiency (Yang et al., 2017), utilization of biofuels instead of fossil fuels (Delangiz et al., 2019). Climatic mitigating strategies include diverse methods such as conventional technologies that include decarbonization and $\mathrm{CO}_{2}$ emission technologies, negative emission technology, including capturing and sequestering $\mathrm{CO}_{2}$ from the atmosphere, potentially removing $\mathrm{CO}_{2}$ and radiative forcing geoengineering technology, including alteration of the earth's radiation balanced by managing solar and terrestrial radiation (Fawzy et al., 2020).
Furthermore, the development of climate-resilient crops is required by integrating modern technological methods. The use of next-generation breeding approaches (Genomic selection and genomic editing), high throughput phenotyping are desirable to develop climate resilient crops (Varshney et al., 2018). Recent progress in genomics and genome editing technologies has been coming across various approaches of genetic study to make climate-resilient crops (Scheben et al., 2016). Several other strategies are incorporated to develop climate resilient/smart crop including SNP genotype, trait mapping and plant breeding methods. Besides this, the role of bioinformatics tools has also been enunciated to tackle stress responses in changing climatic conditions (Laha et al., 2020). The CRISPR/Cas technology has been efficiently used in enhancing productivity in rice crop in fluctuating climatic conditions (Biswal et al., 2019). Similarly, the potential effect of genome editing CRISPR/Cas technology has been depicted to mediate abiotic stress tolerance in different plant species (Zafar et al., 2019). Genetic engineeringthe use of genetically modified organisms, is getting much attention in developing climate-resilient crops to changing climatic conditions. The genetic engineering approach helps manipulate photosynthetic apparatus in climatic alterations (Ortiz et al., 2014). Transgenic technologies have been employed in several crop species in order to confer mitigation to altered climatic conditions (Rubin et al., 2014). Microbial mediated green nanotechnology has emerged as a modern technology to mediate climate resilience. Microbes used in such a process include Bacillus, Fusarium species, Pseudomonas, Aspergillus, Candida albicans, Caulerparacemosa, Tobacco mosaic virus with several other microorganisms. Fabrication of nanoparticles with microbes is a potential method for crop improvement and stress tolerance (Kashyap et al., 2018).

The rhizospheric region possess a vast network of microbial activities that play vital role in several ecological processes like crop production and productivity, nutrient recycling, organic matter decomposition, uptake and recycling of carbon along with storage. In recent years the climatic disruptions have potential effect on rhizospheric ecology and its functioning (Ahkami et al., 2017). Climatic changes including abiotic stresses have additional effect on plant growth and production and they also influence disease development (Glick et al., 2007). Microbes inhabiting the rhizospheric region play an important role in mitigating detrimental effects of climate change which fundamentally causes abiotic stress and pathogen attack. Plants also stimulate secretion of plant growth promoting substances like secondary metabolites, hormones, organic acids which get accumulated in the rhizosphere (rhizodeposition) favoring microbial growth adjacent to or within the plant roots. The root zone also harbors beneficial microorganisms which enhance plant immunity and production (Rodriguez and Durán, 2020). The changing climatic conditions possess adverse effect on rhizospheric and phyllospheric biology. Studies commenced on plant- microbe interactions have unraveled different aspects of symbiotic association of plant with microbes and their beneficial roles in plant health. However, it also demands exploiting the biotechnological strategies by engineering microbial community to enhance plant growth 
under changing climatic conditions. Affirmatively, the microbial engineering can be practiced traditionally, and in recent terms, for understanding different aspects of plant interaction with microbes. Engineered microbes can be used in soil amendments, microbial consortium, microbial breeding, and transplantation techniques, host mediated microbial engineering to develop climate resilient crops (Arif et al., 2020). Rhizosphere supports wide variety of microbial activities. Engineering of rhizosphere influences overall growth, nutrient cycling, carbon allocation, and production of crops which can be achieved by engineering the microbiome. The engineering of rhizosphere with PGPR has fundamental role in nutrient availability, crop sustainability and phytohormone production (Hakim et al., 2021). Plant consists of numerous endophytic microorganisms that reside inside the plant. They perform several physiological functions like resistance to plant pathogen and abiotic stress, plant growth promotion like activities either by synergistic or symbiotic association with the plants. Microbiome engineering also stimulates transfer of several genes, thereby activating multiple functions of the plant at one time (del Carmen Orozco-Mosqueda et al., 2018). Thus, the microbial engineering may have significant effect on agricultural productivity and sustainability along with tolerance to several existing climatic calamities. Studies related to phyllospheric engineering are limited and need greater attention (Wu et al., 2017). The rhizo-engineering and synthetic biology approaches open up the new avenues of interaction of plant with soil microorganisms to provide better adaptation to plants against changing futuristic climatic scenario.

\section{CONCLUSIONS AND FUTURE PERSPECTIVES}

The key issues that influence the plant microbial communities and their dynamics in the plant and the soil are now

\section{REFERENCES}

Abatenh, E., Gizaw, B., Tsegaye, Z., and Tefera, G. (2018). Microbial function on climate change - a review. Open J. Environ. Biol. 3, 001-007. doi: 10.4172/2573-458X.1000147

Abedinzadeh, M., Etesami, H., and Alikhani, H. A. (2018). Characterization of rhizosphere and endophytic bacteria from roots of maize (Zea mays L.) plant irrigated with wastewater with biotechnological potential in agriculture. Biotechnol. Rep. 20:e00305. doi: 10.1016/j.btre.2019.e00305

Aerts, N., Mendes, M. P., and Wees, S. C. M. V. (2020). Multiple levels of crosstalk in hormone networks regulating plant defense. Plant J. 105, 489-504. doi: $10.1111 /$ tpj.15124

Ahkami, A. H., White III, R. A., Handakumbura, P. P., and Jansson, C. (2017). Rhizosphere engineering: enhancing sustainable plant ecosystem productivity. Rhizosphere 3, 233-243. doi: 10.1016/j.rhisph.2017.04.012

Ahmad, I., Akhtar, M. J., Asghar, H. N., Ghafoor, U., and Shahid, M. (2016). Differential effects of plant growth-promoting rhizobacteria on maize growth and cadmium uptake. J. Plant Growth Regul. 35, 303-315. doi: 10.1007/s00344-015-9534-5

Alami, Y., Achouak, W., Marol, C., and Heulin, T. (2000). Rhizosphere soil aggregation and plant growth promotion of sunflowers by exopolysaccharide producing Rhizobium sp. strain isolated from sunflower roots. Appl. Environ. Microbiol. 66, 3393-3398. doi: 10.1128/AEM.66.8.3393-3398.2000 well-known, and research in this aspect is still progress. Our knowledge on understanding the behavior and assemblages of plant microbes above and below the ground, and several factors that influence the plants is still lacking. Microbial association with plants followed two steps: first, recruitment of host-specific plant microbes just close to the root, referred to as rhizosphere, and after that, enter inside the root. Subsequently, various signal molecules coordinate the gathering of the plant microbiomes of rhizosphere and phyllosphere. Signal mechanisms linked to microbiome composition and diversity in their function provide vast scope for future research. Climate change is concurrent phenomenon of global concern and increase in climatic adversity, the food security has been emerged worldwide as alteration in existing climactic patterns adversely affects plant and microbial growth. The adverse effect of climate change is also a matter of discussion for microbe structure \& functioning in ecological niches. To what extent we can manipulate the plant microbiome to increase sustainable agricultural yield, maintaining an eco-friendly environment, needs to be investigated. Recently host genetic factor could facilitate study of microbiome diversity and structure which may help in selection of traits based microbiomes. To explore broader knowledge of the host-specific plant microbe interaction, there is a need of advance integrated novel molecular approaches such as ecological models, meta-omics and bioinformatics that could interlink the correlation between microbial community and environmental function.

\section{AUTHOR CONTRIBUTIONS}

BSH and PD conceptualized and designed the review. BNS and $\mathrm{BSH}$ did the writing of the review. PD reviewed and edited the entire manuscript. All authors contributed to the article and approved the submitted version.

Aleklett, K., Hart, M., and Shade, A. (2014). The microbial ecology of flowers: an emerging frontier in phyllosphere research. Botany 92, 253-266. doi: 10.1139/cjb-2013-0166

Alizadeh, H., Behboudi, K., Ahmadzadeh, M., Javan-Nikkhah, M., Zamioudis, C., Pieterse, C. M. J., et al. (2013). Induced systemic resistance in cucumber and Arabidopsis thaliana by the combination of Trichoderma harzianum Tr6 and Pseudomonas sp. Ps14. Biol. Control 65:14e23. doi: 10.1016/j.biocontrol.2013.01.009

Angilletta, M. J. Jr. (2009). Thermal Adapatation. A Theoretical and Empirical Synthesis. Oxford: Oxford University Press. doi: 10.1093/acprof:oso/9780198570875.001.1

Arif, Y., Singh, P., Siddiqui, H., Bajguz, A., and Hayat, S. (2020). Salinity induced physiological and biochemical changes in plants: An omic approach towards salt stress tolerance. Plant. Physiol. Biochem. 156, 64-77. doi: 10.1016/j.plaphy.2020.08.042

Arroussi, H. E., Benhima, R., Elbaouchi, A., Sijilmassi, B., Mernissi, N. E., Aafsar, A., et al. (2018). Dunaliella salina exopolysaccharides: a promising biostimulant for salt stress tolerance in tomato (Solanum lycopersicum). J. Appl. Phycol. 30, 2929-2941. doi: 10.1007/s10811-017-1382-1

Baloch, G. N., Tariq, S., Ehteshamul-Haque, S., Athar, M., Sultana, V., and Ara, J. (2013). Management of root diseases of eggplant and watermelon with the application of asafoetida and seaweeds. J. Appl. Bot. Food Qual. 86, 138-142. doi: 10.5073/JABFQ.2013.086.019 
Bastiaansen, R., Doelman, A., Eppinga, M. B., and Rietkerk, M. (2020). The effect of climate change on the resilience of ecosystems with adaptive spatial pattern formation. Ecol. Lett. 23, 414-429. doi: 10.1111/ele.13449

Berendsen, R. L., Pieterse, C. M. J., and Bakker, P. A. H. M. (2012). The rhizosphere microbiome and plant health. Trends Plant Sci. 17, 478-486. doi: 10.1016/j.tplants.2012.04.001

Berg, G., Rybakova, D., Grube, M., and Köberl, M. (2016). The plant microbiome explored: implications for experimental botany. J. Exp. Bot. 67, 995-1002. doi: $10.1093 / \mathrm{jxb} / \mathrm{erv} 466$

Bergelson, J., Mittelstrass, J., and Horton, M. W. (2019). Characterizing both bacteria andfungi improves understanding of the Arabidopsis root microbiome. Sci. Rep. 9:24. doi: 10.1038/s41598-018-37208-z

Bhattacharyya, P. N., Goswami, M. P., and Bhattacharyya, L. H. (2016). Perspective of beneficial microbes in agriculture under changing climatic scenario: a review. J. Phytol. 8, 26-41. doi: 10.19071/jp.2016.v8.3022

Biswal, A. K., Mangrauthia, S., Reddy, M., and Yugandhar, P. (2019). CRISPR mediated genome engineering to develop climate smart rice: challenges and opportunities. Semin. Cell Dev. Biol. 96, 100-106. doi: 10.1016/j.semcdb.2019.04.005

Bjerke, J. W., Gwynn-Jones, D., and Callaghan, T. V. (2005). Effects of enhanced UV-B radiation in the field on the concentration of phenolics and chlorophyll fluorescence in two boreal and arctic-alpine lichens. Environ. Exp. Bot. 53, 139-149. doi: 10.1016/j.envexpbot.2004.03.009

Braga, G. U., Rangel, D. E., Fernandes, E. K., Flint, S. D., and Roberts, D. W. (2015). Molecular and physiological effects of environmental UV radiation on fungal conidia. Curr. Genet. 61, 405-425. doi: 10.1007/s00294-015-0483-0

Bruno, L. B., Karthik, C., Ma, Y., Kadirvelu, K., Freitas, H., and Rajkumar, M. (2020). Amelioration of chromium and heat stresses in sorghum bicolor by Cr6+ reducingthermotolerant plant growth promoting bacteria. Chemosphere 244:125521. doi: 10.1016/j.chemosphere.2019.125521

Carrio'n, V. J., Perez-Jaramillo, J., Cordovez, V., Tracanna, V., de Hollander, M., Ruiz-Buck, D., et al. (2019). Pathogen-induced activation of diseasesuppressive functions in the endophytic root microbiome. Science 366, 606-612. doi: $10.1126 /$ science.aaw9285

Cawoy, H., Mariutto, M., Henry, G., Fisher, C., Vasilyeva, N., Thonart, P., et al. (2014). Plant defense stimulation by natural isolates of Bacillus depends on efficient surfactin production. Mol. Plant Microbe Interac. 27, 87-100. doi: 10.1094/MPMI-09-13-0262-R

Chang, P., Gerhardt, K. E., Huang, X. D., Yu, X. M., Glick, B. R., Gerwing, P. D., et al. (2014). Plant growth-promoting bacteria facilitate the growth of barley and oats in salt-impacted soil: implications for phytoremediation of saline soils. Int. J. Phytoremed. 16, 1133-1147. doi: 10.1080/15226514.2013.821447

Chatterjee, P., Samaddar, S., Anandham, R., Kang, Y., Kim, K., Selvakumar, G., et al. (2017). Beneficial soil bacterium Pseudomonas frederiksbergensis OS261 augments salt tolerance and promotes red pepper plant growth. Front. Plant Sci. 8:705. doi: 10.3389/fpls.2017.00705

Chatterjee, S., Sau, G. B., and Mukherjee, S. K. (2009). Plant growth promotion by a hexavalent chromium reducing bacterial strain, Cellulosimicrobium cellulans KUCr3. World J. Microbiol. Biotechnol. 25, 1829-1836. doi: 10.1007/s11274-009-0084-5

Chaudhary, V., Prasanna, R., Nain, L., Dubey, S., Gupta, V., Singh, R., et al. (2012). Bioefficacy of novel cyanobacteria-amended formulations in suppressing damping off disease in tomato seedlings. World J. Microbiol. Biotechnol. 28, 3301-3310. doi: 10.1007/s11274-012-1141-z

Checker, V. G., Kushwaha, H. R., Kumari, P., and Yadav, S. (2018). Role of Phytohormones in Plant Defense: Signaling and Cross Talk. Singapore: Springer. doi: 10.1007/978-981-10-7371-7_7

Chen, C., Xin, K., Hao, L., Juanli, C., Xihui, S., Yao, W., et al. (2017). Pantoea alhagi, a novel endophytic bacterium with ability to improve growth and drought tolerance in wheat. Sci. Rep. 7:41564. doi: 10.1038/srep41564

Chen, J. C., Liu, Q., Yu, L., Korpelainen, H., Niinemets, U., and Li, C. (2021). Elevated temperature and $\mathrm{CO} 2$ interactively modulate sexual competition and ecophysiological responses of dioecious Populus cathayana. For. Ecol. Manag. 481:118747. doi: 10.1016/j.foreco.2020.118747

Cheng, Y. T., Zhang, L.i., and He, S. Y. (2019). Plant-Microbe interactions facing environmental challenge. Cell Host Microbe. 26: 185-192. doi: 10.1016/j.chom.2019.07.009
Chua, A., Sherwood, O. L., Fitzhenry, L., Ng, C. K.-Y., McCabe, P. F., and Daly, C. T. (2020). Cyanobacteria-Derived proline increases stress tolerance in arabidopsis thaliana root hairs by suppressing programmed cell death. Front. Plant Sci. 11:490075. doi: 10.3389/fpls.2020.490075

Cipriano, M. A. P., Freitas-Iório, R. P., Dimitrov, M. R., de Andrade, S. A. L., Kuramae, E. E., Silveira, A. P. D., et al. (2021). Plant-growth endophytic bacteria improve nutrient use efficiency and modulate foliar $\mathrm{N}$-metabolites in sugarcane seedling. Microorganisms 9: 479. doi: 10.3390/microorganisms9030479

Classen, A. T., Sundqvist, M. K., Henning, J. A., Newman, G. S., Moore, J. A. M., Cregger, M. A., et al. (2015). Direct and indirect effects of climate change on soil microbial and soil microbial-plant interactions: what lies ahead? Ecosphere 6:130. doi: 10.1890/ES15-00217.1

Compant, S., Samad, A., Faist, H., and Sessitsch, A. (2019). A review on the plant microbiome: ecology, functions, and emerging trends in microbial application. J. Adv. Res. 19, 29-37. doi: 10.1016/j.jare.2019.03.004

Compant, S., van der Heijden, M. G. A., and Sessitsch, A. (2010). Climate change effects on beneficial plant microorganism interactions. FEMS Microbiol. Soc. 73, 197-214. doi: 10.1111/j.1574-6941.2010.00900.x

Couillerot, O., Vatsa, P., Loqman, S., Ouhdouch, Y., Jane, H., Renault, J.-H., et al. (2013). Biocontrol and biofertilizer activities of the Streptomyces anulatus S37: an endophytic actinomycetewith biocontrol and plant-growth promoting activities. IOBC-WPRS Bull 86, 271-276.

Dastogeer, K. M. G., Tumpa, F. H., Sultana, A., Akter, M. A., and Chakraborty, A. (2020). Plant microbiome-an account of the factors that shape community composition and diversity. Curr. Plant Biol. 23:100161. doi: 10.1016/j.cpb.2020.100161

de Bettignies, T., Wernberg, T., and Gurgel, C. F. D. (2018). Exploring the influence of temperature on aspects of the reproductive phenology of temperate seaweeds. Front. Mar. Sci. 5:218. doi: 10.3389/fmars.2018.00218

De Oliveira, E. D., Bramley, H., Siddique, K. H., Henty, S., Berger, J., and Palta, J. A. (2013). Can elevated CO2 combined with high temperature ameliorate the effect of terminal drought in wheat? Funct. Plant Biol. 40, 160-171. doi: 10.1071/FP12206

de Souza, R. S. C., Armanhi, J. S. L., and Arruda, P. (2020). From microbiome to traits: designing synthetic microbial communities for improved crop resiliency. Front. Plant Sci. 11:1179. doi: 10.3389/fpls.2020.01179

de Vrieze, M., Germanier, F., Vuille, N., and Weisskopf, L. (2018). Combining Di_erent potato-associated pseudomonas strains for improved biocontrol of phytophthora infestans. Front. Microbiol. 9: 2573. doi: 10.3389/fmicb.2018.02573

del Carmen Orozco-Mosqueda, M., del Carmen Rocha-Granados, M., Glick, B. R., and Santoyo, G. (2018). Microbiome engineering to improve biocontrol and plant growth-promoting mechanisms. Microbiol. Res. 208, 25-31. doi: 10.1016/j.micres.2018.01.005

Delangiz, N., Varjovi, M. B., Lajayer, B. A., and Ghorbanpour, M. (2019). The potential of biotechnology for mitigation of greenhouse gasseseffects: solutions, challenges, and future perspectives. Arab. J. Geosci. 12:174. doi: 10.1007/s12517-019-4339-7

Deng, L., Cheung, S., Kang, C. K., Liu, K., Xia, X., and Liu, H. (2021). Elevated temperature relieves phosphorus limitation of marine unicellular diazotrophic cyanobacteria. Limnol. Oceanogr. 9999, 1-13. doi: 10.1002/lno.11980

Díaz, A., Smith, A., Mesa, P., Zapata, J., Caviedes, D., and Cotes, A. M. (2013). "Control of Fusarium Wilt," in Cape Gooseberry by Trichoderma koningiopsis and PGPR, Vol. 86, eds I. Pertot, Y. Elad, E. A. Barka, C. Clément (Dijon: IOBC Bulletin; Working Group Biological Control of Fungal and Bacterial Plant Pathogens, 89-94.

Donhauser, J., Qi, W.,Pinto, B. B., and Frey, B. (2020). High temperatures enhance the microbial genetic potential to recycle $\mathrm{C}$ and $\mathrm{N}$ from necromass in high mountain soils. Glob. Change Biol. 27, 1365-1386. doi: 10.1111/gcb.15492

Dourado, M. N., Martins, P. F., Quecine, M. C., Piotto, F. A., Souza, L. A., Franco, M. R., et al. (2013). Burkholderia sp. SCMS54 reduces cadmium toxicity and promotes growth in tomato. Ann. Appl. Biol. 163, 494-507. doi: 10.1111/aab.12066

Durgadevi, D., Srivignesh, S., and Sankaralingam, A. (2018). Effect of consortia bioformulation of rhizobacteria on induction of systemic resistance in tuberose against peduncle blight disease. Int. J. Bio Resour. Stress Manag. 9, 510-517. doi: 10.23910/IJBSM/2018.9.4.1850b 
Dutta, S. C., and Neog, B. (2016). Accumulation of secondary metabolites in responsible to antioxidant activity of Turmeric rhizomes coinoculated with native arbuscular mycorrhizal fungi and plant growth promoting bacteria. Sci. Hortic. 204, 179-184. doi: 10.1016/j.scienta.2016.03.028

Egamberdieva, D., Kamilova, F., Validov, S., Gafurova, L., Kucharova, Z., and Lugtenberg, B. (2008). High incidence of plant growth-stimulating bacteria associated with the rhizosphere of wheat grown on salinated soil in Uzbekistan. Environ. Microbiol. 10, 1-9. doi: 10.1111/j.1462-2920.2007.01424.x

Egamberdieva, D., Wirth, S., Behrendt, U., Abd-Allah, E. F., and Berg, G. (2016). Biochar treatment resulted in a combined effect on soybean growth promotion and a shift in plant growth promoting rhizobacteria. Front. Microbiol. 7:209. doi: $10.3389 /$ fmicb.2016.00209

Egamberdieva, D., Wirth, S. J., Alqarawi, A. A., Abd_Allah, E. F., and Hashem, A. (2017). Phytohormones and beneficial microbes: essential components for plants to balance stress and fitness. Front. Microbiol. 8:2104. doi: 10.3389/fmicb.2017.02104

Esserti, S., Smaili, A., Rifai, L. A., Koussa, T., Makroum, K., Belfaiza, M., et al. (2016). Protective effect of three brown seaweed extracts against fungal and bacterial diseases of tomato. Environ. Boil. Fish. 29:1081-1093. doi: 10.1007/s10811-016-0996-Z

Estevez de Jensen, C., Percich, J. A., and Graham, P. H. (2002). Integrated management strategies of bean root rot with Bacillus subtilis and Rhizobium in Minnesota. Field Crop Res. 74:e115. doi: 10.1016/S0378-4290(01)00200-3

Etesami, H., Mirsyed Hosseini, H., and Alikhani, H. A. (2014). In planta selection of plant growth promoting endophytic bacteria for rice (Oryza sativa L.). J. Soil Sci. Plant Nutr. 14, 491-503. doi: 10.4067/S0718-95162014005000039

Faist, H., Keller, A., Hentschel, U., and Deeken, R. (2016). Grapevine (Vitis vinifera) crown galls host distinct microbiota. Appl. Environ. Microbiol. 82, 5542-5552. doi: 10.1128/AEM.01131-16

Fawzy, S., Osman, A. I., Doran, J., and Rooney, D. W. (2020). Strategies for mitigation of climate change: a review. Environ. Chem. Lett. 18, 2069-2094. doi: 10.1007/s10311-020-01059-w

Ferrante, A., Nocito, F. F., Morgutti, S., and Sacchi, G. A. (2017). "Plant breeding forimproving nutrient uptake and utilization efficiency," in: Advances in Research on Fertilization Management of Vegetable Crops, eds F. Tei, S.Nicola, P. Benincasa (Cham: Springer International Publishing), 221-246. doi: 10.1007/978-3-319-53626-2_8

Finkel, O. M., Castrillo, G., Paredes, S. H., Gonza' lez, I. S., and Dangl, J. L. (2017). Understanding and exploiting plant beneficial microbes. Curr. Opin. Plant Biol. 38, 155-163. doi: 10.1016/j.pbi.2017.04.018

Foo, E., Plett, J. M., Lopez-Raez, J. A., and Reid, D. (2019). Editorial: the role of plant hormones in plant-microbe symbioses. Front. Plant Sci. 10:1391. doi: $10.3389 /$ fpls.2019.01391

Forni, C., Duca, D., and Glick, B. R. (2017). Mechanisms of plant response to salt and drought stress and their alteration by rhizobacteria. Plant Soil 410, 335-356. doi: 10.1007/s11104-016-3007-x

Frank, A. C., Guzman, J. P. S., and Shay, J. E. (2017). Transmission of bacterial endophytes. Microorganisms 5:70. doi: 10.3390/microorganisms5040070

Fransson, P. M. A., Taylor, A. F. S., and Finlay, R. D. (2005). Mycelial production, spread and root colonization by ectomycorrhizal fungi Hebeloma crustuliniforme and Paxillus involutus under elevated atmospheric $\mathrm{CO} 2$. Mycorrhiza 15, 25-31. doi: 10.1007/s00572-003-0289-7

Frey, S. D., Lee, J., Melillo, J. M., and Six, J. (2013). The temperature response of soil microbial efficiency and its feedback to climate. Nat. Clim. Chang. 3, 395-398. doi: $10.1038 /$ nclimate1796

Gavito, M. E., Curtis, P. S., Mikkelsen, T. N., and Jakobsen, I. (2000). Atmospheric $\mathrm{CO} 2$ and mycorrhiza effects on biomass allocation and nutrient uptake of nodulated pea (Pisum sativum L.) plants. J. Exp. Bot. 51, 1931-1938. doi: 10.1093/jexbot/51.352.1931

Glick, B. R., Todorovic, B., Czarny, J., Cheng, Z., Duan, J., and McConkey, B. (2007). Promotion of plant growth by bacterial ACC deaminase. Critical Rev. Plant Sci. 26, 227-242. doi: 10.1080/07352680701572966

Godbold, D. L., and Berntson, G. M. (1997). Elevated atmospheric CO2 concentration changes ectomycorrhizal morphotype assemblages in Betula papyrifera. Tree Physiol. 17, 347-350. doi: 10.1093/treephys/17.5.347

Grover, M., Maheswari, M., Desaia, S.,Gopinath, K. A., and Venkateswarlu, B. (2015). Elevated CO2: plant associated microorganisms and carbon sequestration. Appl. Soil Ecol. 95, 73-85. doi: 10.1016/j.apsoil.2015.05.006
Gupta, R., and Patil, R. (2021). "Phyllospheric microbes: diversity, functions, interaction, and applications in agriculture," in Current Trends in Microbial Biotechnology for Sustainable Agriculture. Environmental and Microbial Biotechnology, eds A. N. Yadav, J. Singh, C. Singh, and N. Yadav (Singapore: Springer). doi: 10.1007/978-981-15-6949-4_13

Haase, S., Neumann, G., Kania, A., Kuzyakov, Y., Romheld, V., and Kandeler, E. (2007). Elevation of atmospheric CO2 and N-nutritional status modify nodulation, nodule-carbon supply, and root exudation of Phaseolus vulgaris $\mathrm{L}$. Soil Biol. Biochem. 39, 2208-2221. doi: 10.1016/j.soilbio.2007.03.014

Hacquard, S., Spaepen, S., Garrido-Oter, R., and Schulze-Lefert, P. (2017). Interplay between innate immunity and the plant microbiota. Annu. Rev. Phytopathol. 55, 565-589. doi: 10.1146/annurev-phyto-080516-0 35623

Haggag, W., Hoballah, M., and Ali, R. (2018). Applications of nano biotechnological microalgae product for improve wheat productivity in semai-aird areas. Int. J. Agric. Technol. 14, 675-692.

Hakim, S., Naqqash, T., Nawaz, M. S., Laraib, I., Siddique, M. J., Zia, R., et al. (2021). Rhizosphere engineering with plant growth-promoting microorganisms for agriculture and ecological sustainability. Front. Sustain Food Syst. 5:16. doi: 10.3389/fsufs.2021.617157

Hamouda, R. A., and El-Ansary, M. (2017). Potential of plant-parasitic nematode control in banana plants by microalgae as a new approach towards resistance. Egypt. J. Biol. Pest Control 27, 165-172.

Harley, C. D., Anderson, K. M., Demes, K. W., Jorve, J. P., Kordas, R. L., Coyle, T. A., et al. (2012). Effects of climate change on global seaweed communities. J. Phycol. 48, 1064-1078. doi: 10.1111/j.1529-8817.2012.01224.x

Hasan, M. A. (2013). Investigation on the nitrogen fixing cyanobacteria (BGA) in rice fields of North-West region of Bangladesh. III. Filamentous (heterocystous). J. Environ. Sci. Nat. Resour. 6, 253-259. doi: 10.3329/jesnr.v6i1.22075

Hasegawa, H., Chatterjee, A., Cui, Y., and Chatterjee, A. K. (2005). Elevated temperature enhances virulence of Erwinia carotovora subsp. carotovora strain EC153 to plants and stimulates production of the quorum sensing signal, $\mathrm{N}$ acyl homoserine lactone, and extracellular proteins. Appl. Environ. Microbiol. 71, 4655-4663. doi: 10.1128/AEM.71.8.4655-4663.2005

Hassan, T. U., Bano, A., and Naz, I. (2017). Alleviation of heavy metals toxicity by the application of plant growth promoting rhizobacteria and effects on wheat grown in saline sodic field. Int. J. Phytoremed. 19, 522-529. doi: 10.1080/15226514.2016.1267696

Hassani, M. A., Durán, P., and Hacquard, S. (2018). Microbial interactions within the plant holobiont. Microbiome. 6, 1-17. doi: 10.1186/s40168-018-0445-0

Hu, Y. F., Zhou, G., Na, X. F., Yang, L., Nan, W. B., Liu, X., et al. (2013). Cadmium interferes with maintenance of auxin homeostasis in Arabidopsis seedlings. J. Plant Physiol. 170, 965-975. doi: 10.1016/j.jplph.2013. 02.008

Hungate, B. A., Holland, E. A., Jackson, R. B., Chapin, F. S., Mooney, H. A., and Field, C. B. (1997). The fate of carbon in grasslands under carbon dioxide enrichment. Nature 388, 576-579. doi: 10.1038/41550

Huntington, J. L., Hegewisch, K. C., Daudert, B., Morton, C. G., Abatzoglou, J. T., McEvoy, D. J., et al. (2017). Climate engine: cloud computing and visualization of climate and remote sensing data for advanced natural resource monitoring and process understanding. Bull. Am. Meteorol. Soc. 98, 2397-2409. doi: 10.1175/BAMS-D-15-00324.1

Hwang, H. H., Yu, M., and Lai, E. M. (2017). Agrobacterium-mediated plant transformation: biology and applications. Arabidopsis Book 15:0186. doi: 10.1199/tab.0186

Innok, S., Chunleuchanon, S., Boonkerd, N., and Teaumroong, N. (2009). Cyanobacterial akinete induction and its application as biofertilizer for rice cultivation. J. Appl. Phycol. 21:737. doi: 10.1007/s10811-009-9409-x

Islam, W., Noman, A., Naveed, H., Huang, Z., and Chen, H. Y. H. (2020). Role of environmental factors in shaping the soil microbiome. Environ Sci. Pollut. Res. 27, 41225-41247. doi: 10.1007/s11356-020-10471-2

Jain, A., Singh, S., Sarma, B. K., and Singh, H. B. (2012). Microbial consortium-mediated reprogramming of defence network in pea to enhance tolerance against Sclerotinia sclerotiorum. J. Appl. Microbiol. 112, 537-550. doi: 10.1111/j.1365-2672.2011.05220.x

Jaulneau, V., Lafitte, C., Corio-Costet, M.-F., Stadnik, M. J., Salamagne, S., Briand, X., et al. (2011). An ulva armoricana extract protects plants against 
three powdery mildew pathogens. Eur. J. Plant Pathol. 131, 393-401. doi: 10.1007/s10658-011-9816-0

Jia, G., Shevliakova, E., Artaxo, P., Noblet-Ducoudré, N. D., Houghton, R., House, J., et al. (2019). "Land-climate interactions," in Climate Change and Land: An IPCC Special Report on Climate Change, Desertification, Land Degradation, Sustainable Land Management, Food Security, and Greenhouse Gas Fluxes in Terrestrial Ecosystems, eds P.R. Shukla, J. Skea, E. Calvo Buendia, V. MassonDelmotte, H.-O. Pörtner, D.C. Roberts, P. Zhai, R. Slade, S. Connors, R. van Diemen, M. Ferrat, E. Haughey, S. Luz, S. Neogi, M. Pathak, J. Petzold, J. Portugal Pereira, P. Vyas, E. Huntley, K. Kissick, M, Belkacemi, J. Malley.

Jin, X., Zhang, Y., Zhang, P., Trivedi, P., Riera, N., Wang, Y., et al. (2018). The structure and function of the global citrus rhizosphere microbiome. Nat. Commun. 9:4894. doi: 10.1038/s41467-018-07343-2

Jones, J. D. G., Vance, R. E., and Dangl, J. L. (2016). Intracellular innate immune surveillance devices in plants and animals. Science 354:6395. doi: 10.1126/science.aaf6395

Jumpponen, A., Herrera, J., Porras-Alfaro, A., and Rudgers, J. A. (2017). "Biogeography of root-associated fungal endophytes," in Biogeography of Mycorrhizal Symbiosis, ed L. Tedersoo (Cham: Springer), 195-222. doi: 10.1007/978-3-319-56363-3_10

Karhu, K., Auffret, M. D., Dungait, J. A., Hopkins, D. W., Prosser, J. I., Singh, B. K., et al. (2014). Temperature sensitivity of soil respiration rates enhanced by microbial community response. Nature 513, 81-84. doi: 10.1038/nature 13604

Kariman, K., Barker, S. J., and Tibbett, M. (2018). Structural plasticity in rootfungalsymbioses: diverse interactions lead to improved plant fitness. PeerJ. 6:e6030. doi: 10.7717/peerj.6030

Karthiba, L., Saveetha, K., Suresh, S., Raguchander, T., Saravanakumar, D., and Samiyappan, R. (2010). PGPR and entomopathogenic fungus bioformulation for the synchronous management of lea_older pest and sheath blight disease of rice. Pest Manag. Sci. 66, 555-564. doi: 10.1002/ps.1907

Karthikeyan, N., Prasanna, R., Sood, A., Jaiswal, P., Nayak, S., and Kaushik, B. (2009). Physiological characterization and electron microscopic investigation of cyanobacteria associated with wheat rhizosphere. Folia Microbiol. 54, 43-51. doi: 10.1007/s12223-009-0007-8

Kashyap, A. S., Manzar, N., Rajawat, M. V. S., Kesharwani, A. K., Singh, R. P., Dubey, S. C., et al. (2021). Screening and biocontrol potential of rhizobacteria native to gangetic plains and hilly regions to induce systemic resistance and promote plant growth in chilli against bacterial wilt disease. Plants 10:2125. doi: 10.3390/plants10102125

Kashyap, A. S., Pandey, V. K., Manzar, N., Kannojia, P., Singh, U. B., and Sharma, P. K. (2017). "Role of plant growth-promoting rhizobacteria for improving crop productivity in sustainable agriculture," in Plant-Microbe Interactions in AgroEcological Perspectives, eds D. Singh, H. Singh, R. Prabha (Singapore: Springer). doi: 10.1007/978-981-10-6593-4_28

Kashyap, P. L., Rai, P., Kumar, R., Sharma, S., Jasrotia, P., Srivastava, A. K., et al. (2018). Microbial Nanotechnology for Climate Resilient Agriculture, 1st Edn (John Wiley \& Sons, Inc). doi: 10.1002/9781119276050.ch13

Kemble, J. M., Quesada-Ocampo, L. M., Ivors, K. L., Jennings, K. M., and Walgenbach, J. F. (2014). Southeastern US 2014 Vegetable Crop Handbook.

Khan, F. A., Das, G. K., Pande, M., Pathak, M. K., and Sarkar, M. (2011). Biochemical and hormonal composition of follicular cysts in water buffalo (Bubalus bubalis). Animal Reprod. Sci. 124, 61-64. doi: 10.1016/j.anireprosci.2011.02.020

Khan, N., Bano, A., Ali, S., and Babar, M. A. (2020). Crosstalk amongst phytohormones from planta and PGPR under biotic and abiotic stresses. Plant Growth Regul. 90, 189-203. doi: 10.1007/s10725-020-00571-x

Khan, Z., Kim, Y., Kim, S., and Kim, H. (2007). Observations on the suppression of root-knot nematode (Meloidogyne arenaria) on tomato by incorporation of cyanobacterial powder (Oscillatoria chlorina) into potting field soil. Bioresour. Technol. 98, 69-73. doi: 10.1016/j.biortech.2005.11.029

Khan, Z., Park, S., Shin, S., Bae, S., Yeon, I., and Seo, Y. (2005). Management of Meloidogyne incognita on tomato by root-dip treatment in culture filtrate of the blue-green alga, Microcoleus vaginatus. Bioresour. Technol. 96, 1338-1341. doi: 10.1016/j.biortech.2004.11.012

Khondoker, N. A., Uddin, F. J., Sarker, M. A. R., and Rahman, A. (2020). Influence of nitrogen and phosphorus level for the performance of french bean (Phaseolus Vulgaris L.). Acta Scientifica Malaysia (ASM) 4, 34-38. doi: 10.26480 /asm.01.2020.34.38
Kim, J. D. (2006). Screening of cyanobacteria (blue-green algae) from rice paddy soil for antifungal activity against plant pathogenic fungi. Mycobiology 34, 138-142. doi: 10.4489/MYCO.2006.34.3.138

Kim, M.-J., Shim, C.-K., Kim, Y.-K., Ko, B.-G., Park, J.-H., Hwang, S.-G., et al. (2018). Effect of biostimulator Chlorella fusca on improving growth and qualities of chinese chives and spinach in organic farm. Plant Pathol. J. 34:567. doi: 10.5423/PPJ.FT.11.2018.0254

Korner, C., and Arnone, J. A. (1992). Responses to elevated carbondioxide in artificial tropical ecosystems. Science 257, 1672-1675. doi: 10.1126/science.257.5077.1672

Ku, Y.-S., Sintaha, M., Cheung, M.-Y., and Lam, H.-M. (2018). Plant hormone signaling crosstalks between biotic and abiotic stress responses. Int. J. Mol. Sci. 19:3206. doi: 10.3390/ijms19103206

Kudoyarova, G. R., Melentiev, A. I., Martynenko, E. V., Timergalina, L. N., Arkhipova, T. N., Shendel, G. V., et al. (2014). Cytokinin producing bacteria stimulate amino acid deposition by wheat roots. Plant Physiol. Biochem. 83, 285-291. doi: 10.1016/j.plaphy.2014.08.015

Kumar, A., Singh, A. K., Kaushik, M. S., Mishra, S. K., Raj, P., Singh, P. K., et al. (2017). Interaction of turmeric (Curcuma longa L.) with beneficial microbes: a review. 3 Biotech 7:357. doi: 10.1007/s13205-017-0971-7

Laha, A., Chakraborty, P., Banerjee, C., Panja, A. S., and Bandopadhyay, R. (2020). "Application of bioinformatics for crop stress response and mitigation," in Sustainable Agriculture in the Era of Climate Change, eds R. Roychowdhury, S. Choudhury, M. Hasanuzzaman, and S. Srivastava (Springer). doi: 10.1007/978-3-030-45669-6_25

Lee, S.-M., and Ryu, C.-M. (2021). Algae as new kids in the beneficial plant microbiome. Front. Plant Sci. 12:599742. doi: 10.3389/fpls.2021.599742

Lee, S. M., Lee, B., Shim, C. K., Chang, Y. K., and Ryu, C. M. (2020). Plant anti-aging: Delayed flower and leaf senescence in Erinus alpinus treated with cell-free chlorella cultivation medium. Plant Signal. Behav. 15:1763005. doi: 10.1080/15592324.2020.1763005

Lee, Y. J., Kim, S. J., and Jeun, Y. C. (2017). Ultra-structural observations of colletotrichum orbiculare on cucumber leaves pre-treated with Chlorella fusca. Res. Plant Dis. 23, 42-48. doi: 10.5423/RPD.2017.23.1.42

Lee, Y. J., Ko, Y. J., and Jeun, Y. C. (2016). Illustration of disease suppression of anthracnose on cucumber leaves by treatment with Chlorella fusca. Res. Plant Dis. 22, 257-263. doi: 10.5423/RPD.2016.22.4.257

Lesaulnier, C., Papamichail, D., McCorkle, S., Ollivier, B., Skiena, S., Taghavi, S., et al. (2008). Elevated atmospheric CO2 affects soil microbial diversity associated with trembling aspen. Environ. Microbiol. 10, 926-941. doi: 10.1111/j.1462-2920.2007.01512.x

Li, Q., Chen, J., Wu, L., Luo, X., Li, N., Arafat, Y., et al. (2018). Belowground interactions impact the soil bacterial community, soil fertility, and crop yield in maize/peanut intercropping systems. Int. J. Mol. Sci. 19:622. doi: 10.3390/ijms19020622

Li, Y., Xu, S.-S., Gao, J., Pan, S., and Wang, G.-X. (2014). Chlorella induces stomatal closure via NADPH oxidase-dependent ROS production and its effects on instantaneous water use efficiency in Vicia faba. PLoS ONE 9:e93290. doi: 10.1371/journal.pone.0093290

Lin, C. S., Lin, Y. H., and Wu, J. T. (2012). Biodiversity of the epiphyllous algae in a chamaecyparis forest of northern Taiwan. Bot. Stud. 53, 489-499.

Lipson, D. A., Blair, M., Barron-Gafford, G., Grieve, K., and Murthy, R. (2006). Relationships between microbial community structure and soil processes under elevated atmospheric carbon dioxide. Microbiol. Ecol. 51, 302-314. doi: 10.1007/s00248-006-9032-1

Liu, H., and Brettell, L. E. (2019). Plant defense by VOC induced microbial priming. Trends Plant Sci. 24, 187-189. doi: 10.1016/j.tplants.2019.01.008

Ma, Y., Rajkumar, M., and Fritas, H. (2008). Inoculation of plant growth promoting bacterium Achromobacter xylosoxidans strain Ax10 for the improvement of copper phytoextraction by Brassica juncea. J. Environ. Manag. 90, 831-837. doi: 10.1016/j.jenvman.2008.01.014

Malmstrom, C. M., and Field, C. B. (1997). Virus-induced differences in the response of oat plants to elevated carbon dioxide. Plant Cell Environ. 20, 178-188. doi: 10.1046/j.1365-3040.1997.d01-63.x

Manzar, N., Singh, Y., Kashyap, A. S., Sahu, P. K., Rajawat, M. V. S., Bhowmik, A., et al. (2021). Biocontrol potential of native Trichoderma spp. against anthracnose of great millet (Sorghum bicolour L.) from Tarai and hill regions of India. Biol. Control 152, 1049-9644. doi: 10.1016/j.biocontrol.2020.104474 
Martinuz, A., Schouten, A., Menjivar, R., and Sikora, R. (2012). Effectiveness of systemic resistance toward Aphis gossypii (Hom., Aphididae) as induced by combined applications of the endophytes Fusarium oxysporum Fol62 and Rhizobium etli G12. Biol. Control 62, 206-212. doi: 10.1016/j.biocontrol.2012.05.006

Meena, M., Swapnil, P., Zehra, A., Dubey, M. K., and Upadhyay, R. S. (2017). Antagonistic assessment of Trichoderma spp. by producing volatile and nonvolatile compounds against different fungal pathogens. Arch. Phytopathol. Plant Protect. 50, 629-648. doi: 10.1080/03235408.2017.1357360

Mendes, R., Garbeva, P., and Raaijmakers, J. M. (2013). The rhizosphere microbiome: significance of plant beneficial, plant pathogenic, and human pathogenic microorganisms. FEMS Microbiol. Rev. 37, 634-663. doi: 10.1111/1574-6976.12028

Menge, D. N. L., Chisholm, R. A., Davies, S. J., Abu Salim, K., Allen, D., et al. (2019). Patterns of nitrogen-fixing tree abundance in forests across Asia and America. J. Ecol. 107, 2598-2610. doi: 10.1111/1365-2745.13199

Montalbán, B., Thijs, S., Lobo, M. C., Weyens, N., Ameloot, M., Vangronsveld, J., et al. (2017). Cultivar and metal-specific effects of endophytic bacteria in Helianthus tuberosus exposed to Cd and Zn. Int. J. Mol. Sci. 18:2026. doi: 10.3390/ijms18102026

Monz, C. A., Kunt, H. W., Reeves, F. B., and Elliot, E. T. (1994). The response of mycorrhizal colonization to elevated CO2 and climate change in Pascopyrum smithii and Bouteloua gracilis. Plant Soil 165, 75-80. doi: 10.1007/BF00009964

Morella, N. M., Weng, F. C.-H., Joubert, P. M., Metcalf, C. J. E., Lindow, S., and Koskella, B. (2020). Successive passaging of a plant-associated microbiome reveals robust habitat and host genotype-dependent selection. Proc. Natl. Acad. Sci. U.S.A. 117, 1148-1159. doi: 10.1073/pnas.1908600116

Mukherjee, P. K., Hurley, J. F., Taylor, J. T., Puckhaber, L., Lehner, S., Druzhinina, I., et al. (2018). Ferricrocin, the intracellular siderophore of Trichoderma virens, is involved in growth, conidiation, gliotoxin biosynthesis and induction of systemic resistance in maize. Biochem. Biophys. Res. Commun. 505, 606-611. doi: 10.1016/j.bbrc.2018.09.170

Mutale-joan, C., Rachidi, F., Mohamed, H. A., Mernissi, N. E., Aasfar, A., Barakate, M., et al. (2021). Microalgae-cyanobacteria-based biostimulant effect on salinity tolerance mechanisms, nutrient uptake, and tomato plant growth under salt stress. J. Appl. Phycol. 33, 3779-3795. doi: 10.1007/s10811-021-02559-0

Naamala, J., Jaiswal, S. K., and Dakora, F. D. (2016). Microsymbiont diversity and phylogeny of native Bradyrhizobia associated with soybean (Glycine max L. Merr.) nodulation in South African soils. Syst. Appl. Microbiol. 39, 336-344. doi: 10.1016/j.syapm.2016.05.009

Naamala, J., and Smith, D. L. (2020). Relevance of plant growth promoting microorganisms and their derived compounds, in the face of climate change. Agronomy 10, 1179. doi: 10.3390/agronomy10081179

Naseem, H., Ahsan, M., Shahid, M. A., and Khan, N. (2018). Exopolysaccharides producing rhizobacteria and their role in plant growth and drought tolerance. J. Basic Microbiol. 58, 1009-1022. doi: 10.1016/j.jclepro.2018.03.209

Naseem, M., Philippi, N., Hussain, A., Wangorsch, G., Ahmed, N., and Dandekar, T. (2012). Integrated systems view on networking by hormones in Arabidopsis immunity reveals multiple crosstalk for cytokinin. Plant Cell. 24, 1793-1814. doi: $10.1105 /$ tpc. 112.098335

Naya, L., Ladrera, R., Ramos, J., González, E. M., Arrese-Igor, C., Minchin, F. R., et al. (2007). The response of carbon metabolism and antioxidant defences of alfalfa nodules to drought stress and to the subsequent recovery of plants. Plant Physiol. 144, 1104-1114. doi: 10.1104/pp.107.099648

Naylor, D., DeGraaf, S., Purdom, E., and Coleman-Derr, D. (2017). Drought andhost selection influence bacterial community dynamics in the grass root microbiome. ISME J. 11, 2691-2704. doi: 10.1038/ismej.2017.118

Newsham, K. K., Fitter, A. H., and Watkinson, A. R. (1995). Multifunctionality and biodiversity in arbuscular mycorrhizas. Trends Ecol. Evol. 10, 407-411. doi: 10.1016/S0169-5347(00)89157-0

Ortiz, R., Jarvis, A., Fox, P., Aggarwal, P. K., and Campbell, B. M. (2014). Plant Genetic Engineering, Climate Change and Food Security Working Paper No. 72. CGIAR Research Program on Climate Change, Agriculture and Food Security (CCAFS). 10.13140/2.1.4589.7608.

Osono, T. (2006). Role of phyllosphere fungi of forest trees in the development of decomposer fungal communities and decomposition processes of leaf litter. Can. J. Microbiol. 52, 701-716. doi: 10.1139/w06-023
Ostle, N. J. (2008). Microbial contributions to climate change through carbon cycle feedbacks. ISME J. 2, 805-814. doi: 10.1038/ismej.2008.58

Page, T. M., Bergstrom, E., and Diaz-Pulido, G. (2021). Acclimation history of elevated temperature reduces the tolerance of coralline algae to additional acute thermal stress. Front. Mar. Sci. 8:660196. doi: 10.3389/fmars.2021.660196

Panaccione, D. G., Beaulieu, W. T., and Cook, D. (2014). Bioactive alkaloids in vertically transmitted fungal endophytes. Funct. Ecol. 28: 299-314. doi: 10.1111/1365-2435.12076

Pandey, S., and Gupta, S. (2020). Evaluation of Pseudomonas sp. for its multifarious plant growth promoting potential and its ability to alleviate biotic and abiotic stress in tomato (Solanum lycopersicum) plants. Sci. Rep. 10:20951. doi: 10.1038/s41598-020-77850-0

Panneerselvam, P., Kumar, U., Senapati, A., Parameswaran, C., Anandan, A., Kumar, A., et al. (2020). Influence of elevated CO2 on arbuscular mycorrhizal fungal community elucidated using Illumina MiSeq platform in sub-humid tropical paddy soil. Appl. Soil Ecol. 145:103344. doi: 10.1016/j.apsoil.2019.08.006

Park, Y. G., Mun, B. G., Kang, S. M., Hussain, A., Shahzad, R., Seo, C. W. et al. (2017). Bacillus aryabhattai SRB02 tolerates oxidative and nitrosative stress and promotes the growth of soybean by modulating the production of phytohormones. PLOS ONE 12:e0173203. doi: 10.1371/journal.pone.0173203

Paul, G. K., Mahmud, S., Naher, K., Jabin, T., Mahmud, M. L., Haque, M. N., et al. (2020). Isolation and characterization of bacteria from two soil samples and their effect on wheat (Triticum aestivum L.) growth promotion. J. Adv. Biotechnol. Exp. Ther. 3, 254-262. doi: 10.5455/jabet.2020.d132

Penninckx, I. A., Thomma, B. P., Buchala, A., Metraux, J. P., and Broekaert, W. F. (1998). Concomitant activation of jasmonate and ethylene response pathways is required for induction of a plant defensin gene in Arabidopsis. Plant Cell 10, 2103-2113. doi: 10.1105/tpc.10.12.2103

Piisila, M., Keceli, M. A., Brader, G., Jakobson, L., Joesaar, I., Sipari, N., et al. (2015). The F-box protein MAX2 contributes to resistance to bacterial phytopathogens in Arabidopsis thaliana. BMC Plant Biol. 15:53. doi: 10.1186/s12870-015-0434-4

Prasanna, R., Chaudhary, V., Gupta, V., Babu, S., Kumar, A., Singh, R., et al. (2013). Cyanobacteria mediated plant growth promotion and bioprotection against fusarium wilt in tomato. Eur. J. Plant Pathol. 136, 337-353. doi: 10.1007/s10658-013-0167-x

Prasanna, R., Jaiswal, P., Nayak, S., Sood, A., and Kaushik, B. D. (2009). Cyanobacterial diversity in the rhizosphere of rice and its ecological significance. Indian J. Microbiol. 49, 89-97. doi: 10.1007/s12088-009-0009-x

Prasanna, R., Nain, L., Tripathi, R., Gupta, V., Chaudhary, V., Middha, S., et al. (2008). Evaluation of fungicidal activity of extracellular filtrates of cyanobacteria-possible role of hydrolytic enzymes. J. Basic Microbiol. 48, 186-194. doi: 10.1002/jobm.200700199

Querejeta, J. I., Egerton-Warburton, L. M., and Allen, M. F. (2009). Topographic position modulates the mycorrhizal response of oak trees to interannual rainfall variability. Ecology 90, 649-662. doi: 10.1890/07-1696.1

Rashid, M. H., and Chung, Y. R. (2017). Induction of systemic resistance against insect herbivores in plants by beneficial soil microbes. Front. Plant Sci. 8:1816. doi: 10.3389/fpls.2017.01816

Raza, A., Razzaq, A., Mehmood, S. S., Zou, X., Zhang, X., Lv, Y., et al. (2019). Impact of climate change on crops adaptation and strategies to tackle its outcome: a review. Plants 8:34. doi: 10.3390/plants8020034

Recep, K., Fikrettin, S., Erkol, D., and Cafer, E. (2009). Biological control of the potato dry rot caused by Fusarium species using PGPR strains. Bio. Control. 50, 194-198. doi: 10.1016/j.biocontrol.2009.04.004

Reinhold-Hurek, B., Bunger, W., Burbano, C. S., Sabale, M., and Hurek, T. (2015). Roots shaping their microbiome: global hotspots for microbial activity. Annu. Rev. Phytopathol. 53, 403-424. doi: 10.1146/annurev-phyto-082712102342

Rhaman, M. S., Imran, S., Rauf, F., Khatun, M., Baskin, C. C., Murata, Y., et al. (2021). Seed priming with phytohormones: an effective approach for the mitigation of abiotic stress. Plants 10:37. doi: 10.3390/plants100 10037

Rigonato, J., Gonçalves, N., Andreote, A. P. D., Lambais, M. R., and Fiore, M. F. (2016). Estimating genetic structure and diversity of cyanobacterial communities in Atlantic forest phyllosphere. Can. J. Microbiol. 62, 953-960. doi: 10.1139/cjm-2016-0229 
Rodríguez, A., Stella, A., Storni, M., Zulpa, G., and Zaccaro, M. (2006). Effects of cyanobacterial extracellular products and gibberellic acid on salinity tolerance in Oryza sativa L. Saline Syst. 2:7. doi: 10.1186/1746-1448-2-7

Rodriguez, R., and Durán, P. (2020). Natural holobiome engineering by using native extreme microbiome to counteract the climate change effects. Front. Bioeng. Biotech. 8, 568-571. doi: 10.3389/fbioe.2020.00568

Rodriguez, R. J., White, J. F., Arnold, A. E., and Redman, R. S. (2009). Fungal endophytes: diversity and functional roles. New Phytol. 182, 314-330. doi: 10.1111/j.1469-8137.2009.02773.x

Roger, P. A., Zimmerman, W. J., and Lumpkin, T. A. (1993). "Microbiological management of wetland rice fields," in Soil Microbial Ecology: Applications in Agricultural and Environmental Management (New York, NY: Marcel Dekker), $417-455$.

Rolli, E., Marasco, R., Vigani, G., Ettoumi, B., Mapelli, F., Deangelis, M. L., et al. (2015). Improved plant resistance to drought is promoted by the rootassociated microbiome as a water stress-dependent trait. Environ. Microbiol. 17, 316-331. doi: 10.1111/1462-2920.12439

Rubin, E., Shi, W., Moon, C., Leahy, S., Kang, D., Froula, J., et al. (2014). Methane yield phenotypes linked to differential gene expression in the sheep rumen microbiome. Genome Res. 24, 1517-1525. doi: 10.1101/gr.168245.113

Rudgers, J. A., Afkhami, M. E., Bell-Dereske, L., Chung, Y. A., Crawford, K. M., Kivlin, S. N., et al. (2020). Climate disruption of plant-microbe. Annu. Rev. Ecol. Evol. Syst. 51, 561-586. doi: 10.1146/annurev-ecolsys-011720-090819

Rudrappa, T., Czymmek, K. J., Par_e, P. W., and Bais, H. P. (2008). Root-secreted malic acid recruits beneficial soil bacteria. Plant Physiol. 148, 1547-1556. doi: $10.1104 /$ pp. 108.127613

Salas-Marina, M. A., Isordia-Jasso, M. I., Islas-Osuna, M. A., Delgado-Sánchez, P., Jiménez-Bremont, J. F., Rodríguez-Kessler, M., et al. (2015). The Epl1 and Sm1 proteins from Trichoderma atroviride and Trichoderma virens differentially modulate systemic disease resistance against different life style pathogens in Solanum lycopersicum. Front. Plant Sci. 6:77. doi: 10.3389/fpls.2015.00077

Samad, A., Trognitz, F., Compant, S., Antonielli, L., and Sessitsch, A. (2017). Shared and hostspecific microbiome diversity and functioning of grapevine and accompanying weed plants. Environ. Microbiol. 19, 1407-1424. doi: 10.1111/1462-2920.13618

Saravanakumar, D., Lavanya, N., Muthumeena, B., Raguchander, T., Suresh, S., and Samiyappan, R. (2008). Pseudomonas fluorescens enhances resistance and natural enemy population in rice plants against leaffolder pest. J. Applied Entomol. 132, 469-479. doi: 10.1111/j.1439-0418.2008.01278.x

Saravanakumar, D., and Samiyappan, R. (2007). ACC deaminase from Pseudomonas fluorescens mediated saline resistance in groundnut (Arachis hypogea) plants. J. Appl. Microbiol. 102, 1283-1292. doi: $10.1111 / \mathrm{j} .1365-2672.2006 .03179 . \mathrm{x}$

Sarhan, T. Z., and Ismael, S. F. (2014). Effect of low temperature and seaweed extracts on flowering and yield of two cucumber cultivars (Cucumis sativus L.). Int. J. Agric. Food Res. 3, 41-54. doi: 10.24102/ijafr.v3i1.277

Sarma, B. K., Yadav, S. K., Singh, S., and Singh, H. B. (2015). Microbial consortiummediated plant defense against phytopathogens: Readdressing for enhancing efficacy. Soil Biol. Biochem. 87, 25-33. doi: 10.1016/j.soilbio.2015.04.001

Scheben, A., Yuan, Y., and Edwards, D. (2016). Advances in genomics for adapting crops to climate change. Curr. Plant Biol. 6, 2-10. doi: 10.1016/j.cpb.2016.09.001

Schellenbaum, L., Müller, J., Boller, T., Wiemken, A., and Schüepp, H. (1998). Effects of drought on non- mycorrhizal and mycorrhizal maize: changes in the pools of non- structural carbohydrates, in the activities of invertase and trehalase, and in the pools of amino acids and imino acids. New Phytol. 142, 67-77. doi: 10.1046/j.1469-8137.1998.00892.x

Schortemeyer, M., Hartwig, U. A., Hendrey, G. R., and Sadowsky, M. J. (1996). Microbial community changes in the rhizospheres of white clover and perennial ryegrass exposed to free air carbon dioxide enrichment (FACE). Soil Biol. Biochem. 28, 1717-1724. doi: 10.1016/S0038-0717(96) 00243-X

Seifikalhor, M., Hassani, S. B., and Aliniaeifard, S. (2020). Seed priming by cyanobacteria (Spirulina platensis) and salep gum enhances tolerance of maize plant against Cadmium toxicity. J. Plant Growth Regul. 39: 1009-1021. doi: 10.1007/s00344-019-10038-7

Shahzad, R., Waqas, M., Khan, A. L., Asaf, S., Khan, M. A., Kang, S. M., et al. (2016). Seed-borne endophytic Bacillus amyloliquefaciens RWL-1 produces gibberellins and regulates endogenous phytohormones of Oryza sativa. Plant Physiol. Biochem. 106, 236-243. doi: 10.1016/j.plaphy.2016. 05.006

Sharma, A., Shahzad, B., Kumar, V., Kohli, S. K., Sidhu, G. P. S., Bali, A. S., et al. (2019). Phytohormones regulate accumulation of osmolyte s under abiotic stress. Biomolecules 9:285. doi: 10.3390/biom9070285

Shigenaga, A. M., Berens, M. L., Tsuda, K., and Argueso, C. T. (2017). Towards engineering of hormonal crosstalk in plant immunity. Curr. Opin. Plant. Biol. 38, 164-172. doi: 10.1016/j.pbi.2017.04.021

Shilev, S., Babrikova, I., and Babrikov, T. (2019). Consortium of plant growthpromoting bacteria improves spinach (Spinacea oleracea L.) growth under heavy metal stress conditions. J. Chem. Technol. Biotechnol. 95, 932-939. doi: $10.1002 /$ jctb. 6077

Shirinbayan, S., Khosravi, H., and Malakouti, M. J. (2019). Alleviation of drought stress in maize (Zea mays) by inoculation with Azotobacter strains isolated from semi-arid regions. Appl Soil Ecol. 133:138-145. doi: 10.1016/j.apsoil.2018.09.015

Singh, A., Agrawal, M., and Marshall, F. M. (2010). The role of organic vs. inorganic fertilizers in reducing phyto-availability of heavy metals in a wastewaterirrigated area. Eco. Eng. 36, 1733-1740. doi: 10.1016/j.ecoleng.2010.07.021

Singh, A., Jain, A., Sarma, B. K., Upadhyay, R. S., and Singh, H. B. (2013). Rhizosphere competent microbial consortium mediates rapid changes in phenolic profiles in chickpea during Sclerotium rolfsiiinfection. Microbio. Res. 169, 353-360. doi: 10.1016/j.micres.2013.09.014

Singh, R., and Singh, G. S. (2017). Traditional agriculture: a climate-smart approach for sustainable food production. Energ. Ecol. Environ. 2, 296-316. doi: 10.1007/s40974-017-0074-7

Singh, S., and Datta, P. (2007). Outdoor evaluation of herbicide resistant strains of Anabaena variabilis as biofertilizer for rice plants. Plant soil. 296, 95-102. doi: 10.1007/s11104-007-9293-6

Singh, S. P., and Singh, P. (2014). Effect of CO2 concentration on algal growth: review. Renew. Sust. Ener. Rev. 38, 172-179. doi: 10.1016/j.rser.2014.05.043

Singh, V. K., Shukla, A. K., and Singh, A. K. (2019). Impact of climate change on plant-microbe interactions under agroecosystems. Clim. Change Agric. Ecosyst. 2019, 153-179. doi: 10.1016/B978-0-12-816483-9.00007-4

Sørensen, B. E., Grant, T., Ryan, E. J., and Larsen, R. B. (2019). In situ evidence of earthquakes near the crust mantle boundary initiated by mantle $\mathrm{CO} 2$ fluxing and reaction-driven strain softening. Earth Planet Sci. Lett. 524, 115713. doi: 10.1016/j.epsl.2019.115713

Spence, C., Alff, E., Johnson, C., Ramos, C., Donofrio, N., Sundaresan, V., and Bais, H. (2014). Natural rice rhizospheric microbes suppress rice blast infections. BMC. Plant Biol. 14, 1-17. doi: 10.1186/1471-2229-14-130

Staddon, P. L., Gregersen, R., and Jakobsen, I. (2004). The response of two Glomus mycorrhizal fungi and a fine endophyte to elevated atmospheric CO2, soil warming and drought. Glob. Change Biol. 10, 1909-1921. doi: 10.1111/j.1365-2486.2004.00861.x

Stone, B. W. G., Weingarten, E. A., and Jackson, C. R. (2018). The role of the phyllosphere microbiome in plant health and function. Annu. Rev. Plant Biol. 1, 1-24. doi: 10.1002/9781119312994.apr0614

Subramanian, P., Mageswari, A., Kim, K., Lee, Y., and Sa, T. (2015). Psychrotolerant endophytic Pseudomonas sp. strains OB155 and OS261 induced chilling resistance in tomato plants (Solanum lycopersicum Mill.) by activation of their antioxidant capacity. MPMI 28, 1073-1081. doi: 10.1094/MPMI-01-15-0021-R

Tang, J., Xu, L., Chen, X., and Hu, S. (2009). Interaction between C4 barnyard grass and C3 upland rice under elevated CO2: impact of mycorrhizae. Acta Oecol. 35, 227-235. doi: 10.1016/j.actao.2008.10.005

Tecon, R., and Or, D. (2017). Biophysical processes supporting the diversity of microbial life in soil. FEMS. Microbiol Rev. 41:599-623. doi: 10.1093/femsre/fux039

Thind, T. S., and Schilder, A. C. (2018). Understanding photoreception in fungi and its role in fungal development with focus on phytopathogenic fungi. Indian Phytopathol. 71, 169-182. 10.1007/s42360-018-0025-Z doi: 10.1007/s42360-018-0025-z

Thompson, I. P., Bailey, M. J., Fenlon, J. S., Fermor, T. R., Lilley, A. K., Lynch, J. M., et al. (1993). Quantitative and qualitative seasonal changes in the microbial community from the phyllosphere of sugar beet (Beta vulgaris). Plant Soil. 150, 177-191. doi: 10.1007/BF00013015 
Timm, C. M., Carter, K. R., Carrell, A. A., Jun, Se-Ran., Jawdy, S. S., Vélez, J. M., et al. (2018). Abiotic stresses shift belowground populus-associated bacteria toward a core stress microbiome. mSystems 3, e00070-e00017. doi: 10.1128/mSystems.00070-17

Toumatia, O., Compant, S., Yekkour, A., Goudjal, Y., Sabaou, N., Mathieu, F., et al. (2016). Biocontrol and plant growth promoting properties of Streptomyces mutabilis strain IA1 isolated from a Saharan soil on wheat seedlings and visualization of its niches of colonization. South African J. Bot. 105, 234-239. doi: 10.1016/j.sajb.2016.03.020

Tripathi, P., Singh, P. C., Mishra, A., Srivastava, S., Chauhan, R., Awasthi, S., et al. (2017). Arsenic tolerant Trichoderma sp. reduces arsenic induced stress in chickpea (Cicer arietinum). Environ. Pollut. 223, 137-145. doi: 10.1016/j.envpol.2016.12.073

Trivedi, P., Leach, J. E., Tringe, S. G., Sa, T., and Singh, B. K. (2020). Plantmicrobiome interactions: from community assembly to plant health. Microbiol. Nat. 18, 608-621. doi: 10.1038/s41579-020-0412-1

Tsai, D. D. W., Chen, P. H., and Ramaraj, R. (2017). The potential of carbon dioxide capture and sequestration with algae. Ecol. Eng. 98, 17-23. doi: 10.1016/j.ecoleng.2016.10.049

Tsavkelova, E. A., Cherdyntseva, T. A., Klimova, S. Y., Shestakov, A. I., Botina, S. G., and Netrusov, A. I. (2007). Orchid-associated bacteria produce indole-3-acetic acid, promote seed germination, and increase their microbial yield in response to exogenous auxin. Arch. Microbiol. 188, 655-664. doi: 10.1007/s00203-007-0286-x

Ullah, F., Papini, A., Shah, S. N., Zaman, W., Sohail, A. and Iqbal, M. (2019). Seed micromorphology and its taxonomic evidence in subfamily Alsinoideae Caryophyllaceae). Microsc. Res. Tech. 82, 250-259. doi: 10.1002/jemt.23167

Upadhyay, S. K., Singh, J. S., Saxena, A. K., and Singh, D. P. (2012). Impact of PGPR inoculation on growth and antioxidant status of wheat under saline conditions. Plant Biol. 14, 605-611. doi: 10.1111/j.1438-8677.2011.00533.x

USDA. (2016). A Guide to Smart Snacks in School. Washington: Food \& Nutrition Service.

Vaishampayan, A., Sinha, R. P., Hader, D. P., Dey, T., Gupta, A. K., Bhan, U., et al. (2001). Cyanobacterial biofertilizers in rice agriculture. Bot. Rev. 67, 453-516. doi: 10.1007/BF02857893

Vanhaelewyn, L., Van Der Straeten, D., De Coninck, B., and Vandenbussche, F. (2020). Ultraviolet radiation from a plant perspective: the plant-microorganism context. Front. Plant Sci. 11:597642. doi: 10.3389/fpls.2020.597642

Vargas, L., Santa Brigida, A. B., Mota Filho, J. P., De Carvalho, T. G., Rojas, C. A., Vaneechoutte, D., et al. (2014). Drought tolerance conferred to sugarcane by association with Gluconacetobacter diazotrophicus: a transcriptomic view of hormone pathways. PLoS ONE, 9, e114744. doi: 10.1371/journal.pone.0114744

Varshney, R. K., Singh, V. K., Kumar, A., Powell, W., and Sorrells, M. E. (2018). Can genomics deliver climate-change ready crops?. Curr. Opin. Plant Biol. 45, 205-211. doi: 10.1016/j.pbi.2018.03.007

Vela'squez, A. C., Castroverde, C. D. M., and He, S. Y. (2018). Plantpathogenwarfare under changing climate conditions. Curr. Biol. 28, R619R634. doi: 10.1016/j.cub.2018.03.054

Venkatachalam, S., Ranjan, K., Prasanna, R., Ramakrishnan, B., Thapa, S., Kanchan, A., et al. (2016). Diversity and functional traits of culturable microbiome members, including cyanobactera in the rice phyllosphere. Plant Biol. 18, 627-637. doi: 10.1111/plb.12441

Verbon, E. H., and Liberman, L. M. (2016). Beneficial microbes affect endogenous mechanisms controlling root development. Trends Plant Sci. 21, 218-229. doi: 10.1016/j.tplants.2016.01.013

Verheijen, L., Aerts, R., Brovkin, V., Cavender-Bares, J., Cornelissen, J., Kattge, J., et al. (2015). Inclusion of ecologically based trait variation in plant functional types reduces the projected land carbon sink in an earth system model. Glob. Change Biol. 21, 3074-3086. doi: 10.1111/gcb.12871

Vigani, G., Rolli, E., Marasco, R., Dell'Orto, M., Michoud, G., Soussi, A., et al. (2019). Root bacterial endophytes confer drought resistance and enhance expression and activity of a vacuolar $\mathrm{H}+$-pumping pyrophosphatase in pepper plants. Environ. Microbio. 21, 3212-3228. doi: 10.1111/1462-2920. 14272

Vinale, F., and Sivasithamparam, K. (2020). Beneficial effects of trichoderma secondary metabolites. Phytother. Res. 34, 1-8. doi: 10.1002/ptr.6728

Vinale, F., Sivasithamparam, K., Ghisalberti, E. L., Marra, R., Barbetti, M. J., $\mathrm{Li}, \mathrm{H}$., et al. (2008a). A novel role for trichoderma secondary metabolites in the interactions with plants. Physiol. Mol. Plant Pathol. 72, 80-86. doi: 10.1016/j.pmpp.2008.05.005

Vinale, F., Sivasithamparam, K., Ghisalberti, E. L., Marra, R., Woo, S. L., and Lorito, M. (2008b). trichoderma-plant-pathogen interactions. Soil Biol. Biochem. 40, 1-10. doi: 10.1016/j.soilbio.2007.07.002

Vorholt, J. A. (2012). Microbial life in the phyllosphere. Nat. Rev. Microbiol. 10, 828-840. doi: 10.1038/nrmicro2910

Walitang, D. I., Kim, K., Madhaiyan, M., Kim, Y. K., Kang, Y., and Sa, T. (2017). Characterizing endophytic competence and plant growth promotion of bacterial endophytes inhabiting the seed endosphere of Rice. BMC Microbiol. 17:209. doi: 10.1186/s12866-017-1117-0

Wallace, J., Kremling, K. A., Kovar, L. L., and Buckler, E. S. (2018). Quantitative genetics of the maize leaf microbiome. Phytobiomes J. 2, 208-224. doi: 10.1094/PBIOMES-02-18-0008-R

Wang, J., Wang, Y., Song, X., Wang, Y., and Lei, X. (2017). Elevated atmospheric $\mathrm{CO} 2$ and drought affect soil microbial community and functional diversity associated with glycine max. Rev. Bras. Cienc. Solo. 41, 1-12. doi: 10.1590/18069657rbcs20160460

Wang, Q., Dodd, I. C., Belimov, A. A., and Jiang, F. (2016). Rhizosphere bacteria containing 1-aminocyclopropane-1-carboxylate deaminase increase growth and photosynthesis of pea plants under salt stress by limiting $\mathrm{Na}+$ accumulation. Funct. Plant Biol. 43, 161-172. doi: 10.1071/FP15200

Wang, X., Wang, C., Cotrufo, M. F., Sun, L., Jiang, P., and Bai, E. (2020). Elevated temperature increases the accumulation of microbial necromass nitrogen in soil via increasing microbial turnover. Glob. Change Biol. 26, 5277-5289. doi: $10.1111 /$ gcb.15206

Weilharter, A., Mitter, B., Shin, M. V., Chain, P. S., Nowak, J., and Sessitsch, A. (2011). Complete genome sequence of the plant growthpromoting endophyte Burkholderia phytofirmans strain PsJN. J. Bacteriol. 193, 3383-3384. doi: 10.1128/JB.05055-11

Williams, A., Pétriacq, P., Beerling, D. J., Cotton, T. E. A., and Ton, J. (2018). Impacts of atmospheric CO2 and soil nutritional value on plant responses to rhizosphere colonization by soil bacteria. Front. Plant Sci. 9:1493. doi: 10.3389/fpls.2018.01493

Winkel, T., Renno, J.-F., and Payne, W. (1997). Effect of the timing of water deficit on growth, phenology and yield of pearl millet (Pennisetum glaucum (L.) R. Br.) grown in sahelian conditions. J. Exp. Bot. 48, 1001-1009. doi: 10.1093/jxb/48.5.1001

Wu, Y., Lin, H., Lin, Y., Shi, J., Xue, S., Hung, Y., et al. (2017). E_ects of biocontrol bacteria Bacillus amyloliquefaciens LY-1 culture broth on quality attributes and storability of harvested litchi fruit. Postharvest Biol. Technol. 132: 81-87. doi: 10.1016/j.postharvbio.2017.05.021

Xu, L., Naylor, D., Dong, Z., Simmons, T., Pierroz, G., Hixson, K. K., et al. (2018). Drought delays development of the sorghum root microbiome and enriches for monoderm bacteria. Proc. Natl. Acad. Sci. 115, E4284-E4293. doi: 10.1073/pnas.1717308115

Xu, M., He, D. Z., Wu, Y., van Nostrand, L., Hobbie, J. D., Reich, S. E., et al. (2013). Elevated CO2 influences microbial carbon and nitrogen cycling. BMC Microbiol. 13:124. doi: 10.1186/1471-2180-13-124

Xu, X. M., Jeffries, P., Pautasso, M., and Jeger, M. J. (2011). Combined use of biocontrol agents to manage plant diseases in theory and practice. Phytopathology 101, 1024-1031. doi: 10.1094/PHYTO-08-10-0216

Yandigeri, M. S., Meena, K. K., Singh, D., Malviya, N., Singh, D. P., Solanki, M. K. A., et al. (2012). Drought-tolerant endophytic actinobacteria promote growth of wheat (Triticum aestivum) under water stress conditions. Plant Growth Regul. 68, 411-420. doi: 10.1007/s10725-012-9730-2

Yáñez-López, R., Torres-Pacheco, I., Guevara-González, R. G., Hernández-Zul, M. I., Quijano-Carranza, J. A., and Rico-García, E. (2012). The effect of climate change on plant diseases. R. Afr. J. Biotechnol. 11, 2417-2428. doi: $10.5897 / A J B 10.2442$

Yang, B., Liu, J. M., Xiaonian, G. B., Liu, B., Wu, T., Jiang, Y., et al. (2017). Genetic engineering of the Calvin cycle toward enhanced photosyn-thetic CO2 fixation in microalgae. Biotechnol. Biofuels. 10:229. doi: 10.1186/s13068-0170916-8

Yu, H., He, Z., Wang, A., Xie, J., Wu, L., Van Nostrand, J. D., et al. (2018). Divergent responses of forest soil microbial communities under elevated $\mathrm{CO} 2$ in different depths of upper soil layers. Appl. Environ. Microbiol. 84, e01694-e01617. doi: 10.1128/AEM.01694-17 
Zafar, S., Zaidi, S. S., Gaba, Y., Singla-Pareek, S., Dhankher, O. P., Li, X., Mansoor, S., and Pareek, A. (2019). Engineering Abiotic Stress Tolerance via CRISPR-Cas mediated genome editing. Journal of experimental botany. 71 . 10.1093/jxb/erz476. doi: 10.1093/jxb/erz476

Zaheer, A., Mirza, B. S., Mclean, J. E., Yasmin, S., Shah, S. M., Malik, K. A., et al. (2016). Association of plant growth-promoting Serratia spp. with the root nodules of chickpea. Res. Microbiol. 167, 510-520. doi: 10.1016/j.resmic.2016.04.001

Zeeshan, M., and Prasad, S. M. (2009). Differential response of growth, photosynthesis, antioxidant enzymes and lipid peroxidation to UV-B radiation in three cyanobacteria. South African J. Bot. 75, 466-474. doi: 10.1016/j.sajb.2009.03.003

Zhang, C., and Xi, N. (2021). Precipitation changes regulate plant and soil microbial biomass via plasticity in plant biomass allocation in grasslands: a meta-analysis. Front. Plant Sci. 12:614968. doi: 10.3389/fpls.2021.614968

Zhang, Y., Yan, X., Guo, H., Zhao, F., and Huang, L. (2018). A novel protein elicitor BAR11 from Saccharothrix yanglingensis Hhs.015 improves plant resistance to pathogens and interacts with catalases as targets. Front. Microbiol. 9:700. doi: $10.3389 /$ fmicb. 2018.00700

Zhu, H., Li, S., Hu, Z., and Liu, G. (2018). Molecular characterization of eukaryotic algal communities in the tropical phyllosphere based on real-time sequencing of the 18S rDNA gene. BMC Plant Biol. 18:365. doi: 10.1186/s12870-018$1588-7$
Zogg, G. P., Zak, D. R., Ringelberg, D. B., White, D. C., MacDonald, N. W., and Pregitzer, K. S. (2010). Compositional and functional shifts in microbial communities due to soil warming. Soil Sci. Soc. Am. J. 61, 475-481. doi: $10.2136 /$ sssaj $1997.03615995006100020015 x$

Conflict of Interest: The authors declare that the research was conducted in the absence of any commercial or financial relationships that could be construed as a potential conflict of interest.

Publisher's Note: All claims expressed in this article are solely those of the authors and do not necessarily represent those of their affiliated organizations, or those of the publisher, the editors and the reviewers. Any product that may be evaluated in this article, or claim that may be made by its manufacturer, is not guaranteed or endorsed by the publisher.

Copyright $\odot 2022$ Sharma, Singh, Dwivedi and Rajawat. This is an open-access article distributed under the terms of the Creative Commons Attribution License (CC $B Y)$. The use, distribution or reproduction in other forums is permitted, provided the original author(s) and the copyright owner(s) are credited and that the original publication in this journal is cited, in accordance with accepted academic practice. No use, distribution or reproduction is permitted which does not comply with these terms. 